\title{
Review
}

\section{Sacroiliac Joint Interventions: A Systematic Review}

Hans C. Hansen, MD' ${ }^{1}$, Anne Marie McKenzie-Brown, MD², Steven P. Cohen, MD, John R. Swicegood, MD ${ }^{4}$, James D. Colson, MD ${ }^{5}$ and Laxmaiah Manchikanti, MD ${ }^{6}$

From: ${ }^{\top}$ The Pain Relief Center, Conover, NC; ${ }^{2}$ Emory Center for Pain Medicine, Atlanta, GA; ${ }^{3}$ Johns Hopkins School of Medicine, Washington,

DC; ${ }^{4}$ Advanced Interventional Pain and Diagnostics of Western Arkansas, Fort Smith, AR; and ${ }^{5}$ West

Virginia University Hospitals; ${ }^{\circ}$ Pain Management Center of Paducah and University of Louisville, Louisville, KY. Dr. Hansen ${ }^{1}$ is Medical Director, The

Pain Relief Centers, Conover, NC. Dr. McKenzie-Brown ${ }^{2}$ is Assistant Professor of Anesthesiology, Division Director, Division of Pain Medicine, Emory Department of Anesthesiology, Emory Center for

Pain Medicine, Atlanta, GA. Dr. Cohen ${ }^{3}$ is Associate Professor, Department of Anesthesiology and Critical Care Medicine, Pain Management Division, Johns Hopkins School of Medicine, Baltimore, MD; and Director of Chronic Pain Research, Walter Reed Army Medical Center, Washington,

DC. Dr. Swicegood 4 is Medical

Director, Advanced Interventional

Pain and Diagnostics of Western Arkansas, Fort Smith, AR. Dr. Colson ${ }^{5}$ is Associate Professor of Anesthesiology, Department of Anesthesiology, Pain Medicine Service, West Virginia University Hospitals. Dr. Manchikanti is Medical Director, Pain Management Center of Paducah, Paducah, KY; and Associate Clinical Professor of Anesthesiology and Perioperative Medicine, University

of Louisville, Louisville, KY. Address Correspondence: Hans C. Hansen, MD, The Pain Relief Centers, 1224 Commerce Street SW, Conover, NC 28613 E-mail: hans@hippocrates.org Funding: None

Conflict of Interest: None.

Free Full manuscript

www.painphysicianjournal.com
Background: The sacroiliac joint is a diarthrodial synovial joint with abundant innervation and capability of being a source of low back pain and referred pain in the lower extremity. There are no definite historical, physical, or radiological features to provide definite diagnosis of sacroiliac joint pain, although many authors have advocated provocational maneuvers to suggest sacroiliac joint as a pain generator. An accurate diagnosis is made by controlled sacroiliac joint diagnostic blocks. The sacroiliac joint has been shown to be a source of pain in $10 \%$ to $27 \%$ of suspected cases with chronic low back pain utilizing controlled comparative local anesthetic blocks. Intraarticular injections, and radiofrequency neurotomy have been described as therapeutic measures. This systematic review was performed to assess diagnostic testing (non-invasive versus interventional diagnostic techniques) and to evaluate the clinical usefulness of interventional techniques in the management of chronic sacroiliac joint pain.

Objective: To evaluate and update the available evidence regarding diagnostic and therapeutic sacroiliac joint interventions in the management of sacroiliac joint pain.

Study Design: A systematic review using the criteria as outlined by the Agency for Healthcare Research and Quality (AHRQ), Cochrane Review Group Criteria for therapeutic interventions and AHRQ, and Quality Assessment for Diagnostic Accuracy Studies (QUADAS) for diagnostic studies.

Methods: The databases of EMBASE and MEDLINE (1966 to December 2006), and Cochrane Reviews were searched. The searches included systematic reviews, narrative reviews, prospective and retrospective studies, and cross-references from articles reviewed. The search strategy included sacroiliac joint pain and dysfunction, sacroiliac joint injections, interventions, and radiofrequency.

Results: The results of this systematic evaluation revealed that for diagnostic purposes, there is moderate evidence showing the accuracy of comparative, controlled local anesthetic blocks. Prevalence of sacroiliac joint pain is estimated to range between $10 \%$ and $27 \%$ using a double block paradigm. The false-positive rate of single, uncontrolled, sacroiliac joint injections is around $20 \%$. The evidence for provocative testing to diagnose sacroiliac joint pain is limited.

For therapeutic purposes, intraarticular sacroiliac joint injections with steroid and radiofrequency neurotomy were evaluated. Based on this review, there is limited evidence for short-term and longterm relief with intraarticular sacroiliac joint injections and radiofrequency thermoneurolysis.

Conclusions: The evidence for the specificity and validity of diagnostic sacroiliac joint injections is moderate. The evidence for accuracy of provocative maneuvers in diagnosis of sacroiliac joint pain is limited. The evidence for therapeutic intraarticular sacroiliac joint injections is limited. The evidence for radiofrequency neurotomy in managing chronic sacroiliac joint pain is limited.

Keywords: Low back pain, sacroiliac joint pain, axial pain, spinal pain, diagnostic block, sacroiliac joint injection, thermal radiofrequency, and pulsed radiofrequency.

Pain Physician 2007; 10:165-184 
$T$ he sacroiliac joint has been implicated as the primary source of pain (1-7) in $10 \%$ to $26.6 \%$ (8-10) of cases with suspected sacroiliac joint pain utilizing controlled comparative local anesthetic blocks on patients based on International Association for the Study of Pain (IASP) criteria (11). Until Mixter and Barr (12) in 1934 described disc herniation as a source of pain in the lumbar spine, the sacroiliac joint was widely considered a major source of back pain (17,13-15). The evidence supporting the sacroiliac joint as a pain generator was largely empirical, however being mostly derived from successful treatment of patients with suspected sacrioliac joint pain. The sacroiliac joint is unable to function in isolation; anatomically and biomechanically it shares all of its muscles with the hip joint. Ligamentous structures and the muscles they support affect much of the stability of the sacroiliac joint $(2-5,7,15-18)$. These include the very strong interosseous ligaments as well as the iliolumbar, sacrotuberous, and sacrospinous ligaments. Sacroiliac joint pain may be the result of direct trauma, unidirectional pelvic shear, repetitive and torsional forces, inflammation, or idiopathic onset (2-5,7,15-17).

The sacroiliac joint is a diarthrodial joint (18). The sacroiliac joint receives innervation from the lumbosacral nerve roots $(14,19-27)$. Fortin et al (20), based on an anatomic study on adult cadavers, concluded that the sacroiliac joint is predominantly, if not entirely, innervated by sacral dorsal rami. Murata et al (19) illustrated that sensory nerve fibers supplying the dorsal side of the sacroiliac joint derived from the dorsal root ganglions of the lower lumbar and sacral levels (from L4 to S2), and those innervating the ventral side originated from the dorsal root ganglions of the upper lumbar, lower lumbar, and sacral levels (from L1 to S2). Vilensky et al (23) demonstrated the presence of nerve fibers and mechanoreceptors in the sacroiliac ligament.

Cohen (2) reviewed the complex and controversial innervation of the sacroiliac joint. The lateral branches of the L4 to S3 dorsal rami are cited by some experts as comprising the major innervation to the posterior sacroiliac joint (14). Other investigators claimed that L3 and S4 contribute to the posterior nerve supply $(19,21)$. The literature suggests the anterior joint is innervated by L2 through S2 (14), and the L5 to S2 ventral rami (22). Neurophysiologic studies have demonstrated both nociceptive and proprioceptive afferent units in the sacroiliac joint $(23,24,28,29)$. The average mechanical threshold of a sacroiliac joint nociceptive unit was found to be much higher than lumbar facet joint nociceptive units (70 grams vs 6 grams), but lower than the 241 grams threshold for units residing in the anterior lumbar disc $(26,28,29)$, indicating that the pain sensitivity of the sacroiliac joints may be lower than that of lumbar facet joints, but higher than the anterior portions of the lumbar discs.

Referral patterns based on sacroiliac joint provocation and analgesia have been published. Fortin et al (30) generated a pain referral map using contrast injection provocation, followed by local anesthetic injection into the sacroiliac joint in 10 asymptomatic volunteers. Fortin et al (31) also evaluated the applicability of a pain referral map as a screening tool for sacroiliac joint dysfunction. Slipman et al (32) also demonstrated sacroiliac joint pain referral zones based on analgesic response to low-volume local anesthetic injection. Schwarzer et al (33) found the only distinguishing pattern of the patients who responded to sacroiliac joint injections to be groin pain.

The rationale for the use of sacroiliac joint blocks as gold standard for diagnosing sacroiliac joint pain is based upon the fact that sacroiliac joints are richly innervated and have been shown to be capable of being a source of low back pain and referred pain in the lower extremity $(1-11,14,15,19-29)$. There are no absolute historical, physical, or radiological features to provide definitive diagnosis of sacroiliac joint pain (32-68). The diagnosis of symptomatic sacroiliac joint pathology may mean that either sacroiliac joint contains the pain generating tissues, or that the sacroiliac joint functions or malfunctions in such a way as to cause pain (36). A corroborative history and physical examination can enter into the differential diagnosis of sacroiliac joint pain, but cannot make a definitive diagnosis of sacroiliac joint syndrome. Similarly, radiologic evaluation is inconclusive $(10,69-83)$. In spite of reports of the efficacy of plain films $(7,69)$, computed tomography (78), single photon emission computed tomography $(70)$, bone scans $(71,72)$, nuclear imaging $(10,72-76)$, and magnetic resonance imaging (77-80) in delineating radiographic sacroiliac joint abnormalities, there are no definitive corroborative radiologic findings and reliably identified in patients with sacroiliac joint syndrome. Associations have been found between a history of prior spinal surgery and sacroiliac joint pain $(10,82,83)$.

Diagnostic injections of a sacroiliac joint can be 
performed in order to determine if the sacroiliac joint is the source of the patient's pain (7-11,84). The sacroiliac joint can be anesthetized with intraarticular injection of local anesthetic performed under fluoroscopic guidance with confirmation of contrast spread throughout the joint space. Similarly, intraarticular injections with steroid and radiofrequency neurotomy have been employed to manage chronic sacroiliac joint pain $(1,6)$.

To date there has been only one high quality systematic evaluation of the evidence of diagnostic sacroiliac joint injections or therapeutic sacroiliac joint injections (1). McKenzie-Brown et al (1) in 2004 performed the first systematic review on sacroiliac joint interventions utilizing the AHRQ, Cochrane Review Group criteria, and QUADAS criteria for diagnostic studies. They concluded that the evidence for the specificity and validity of diagnostic sacroiliac joint injections was moderate. The evidence for therapeutic intraarticular sacroiliac joint injections was limited to moderate. Finally, the evidence for radiofrequency neurotomy in managing chronic sacroiliac joint pain was limited. European guidelines for the management of chronic non-specific low back pain by Airaksinen et al (85) published in 2006 included the literature published through 2002. They concluded that there is limited evidence that injection of the sacroiliac joint with corticosteroids relieves sacroiliac joint pain for a short time (Level C).

Multiple studies have appeared since the aforementioned publications. Hence, we have undertaken this systematic review was undertaken to assess and update the level of evidence for diagnostic and therapeutic sacroiliac joint interventions.

\section{Methods}

\section{Search Strategy}

The databases of EMBASE, PubMed/MEDLINE, MD Consult, and Cochrane Database search were performed through December 2006.

The searches included systematic reviews, narrative reviews, prospective and retrospective studies, and cross-references from articles reviewed.

The search strategy included key words or terms: sacroiliac joint pain and dysfunction, sacroiliac joint injections, and sacroiliac joint radiofrequency.

One reviewer assessed the quality of the articles for inclusion. Three reviewers evaluated the studies. A list was generated of the abstracts reviewed. If there were no clear exclusion criteria within the abstract then the full article was reviewed. Those articles were then analyzed based on their study population, outcome, and quality.

\section{Inclusion Criteria}

Types of Studies

Study designs that used controlled and uncontrolled studies of sacroiliac joint injections were included.

\section{Types of Participants}

Subjects with low back pain with or without leg pain for at least 3 months; participants had tried and failed conservative management; pain sufficient to be referred to a pain specialist/spinal injectionist for the diagnostic injection.

Types of Interventions

Local anesthetic injections, placebo controlled injections, controlled comparative local anesthetic sacroiliac joint injections, sacroiliac joint injections with local anesthetic and steroid, and radiofrequency neurotomy (thermal and pulsed).

Types of Outcome Measures

Pain relief of $50 \%$ or greater was the main outcome measure.

\section{Exclusion criteria}

Types of Studies

Case reports, descriptive reports.

Types of Participants

Participants with pain symptoms for $<3$ months, sacroiliac joint injections performed on animals.

Types of Interventions

Single injections, non-fluoroscopic /non-radiographically guided injections, surgical interventions (fusions, fixations).

Follow-up

Less than 3 months.

\section{Methodological Quality}

Methodological quality of articles was assessed by the criteria established by AHRQ (86), criteria described for QUADAS (87), and Cochrane Review Group for randomized trials (88).

The details of application of these criteria are illustrated in various tables in this journal in the manuscripts of An Updated Systematic Review of the Diagnostic Utility of Selective Nerve Root Blocks, Systematic Review of Discography as a Diagnostic Test for Spinal Pain: An Update, Systematic Review of Diagnostic Utility of Facet (Zygapophysial) Joint Injections in Chronic Spinal Pain: An 
Update, and Systematic Review of Effectiveness and Complications of Adhesiolysis in the Management of Chronic Spinal Pain: An Update, and elsewhere $(6,88-92)$.

\section{Analysis of Evidence}

Qualitative analysis was conducted using 5 levels of evidence as shown in Table 1.

For therapeutic intraarticular injections, the primary outcome measure was significant pain relief $(>50 \%)$. Other outcome measures utilized were functional improvement, psychological improvement, and return to work or work status. For therapeutic interventions with intraarticular injections short-term relief was defined as less than 6 weeks, and long-term relief was defined as 6 weeks or longer. In contrast, for radiofrequency neurotomy, short-term relief was defined as less than 3 months and long-term relief was defined as 3 months or longer.

For diagnostic interventions placebo controlled or comparative, controlled local anesthetic blocks were considered as satisfactory criteria. The criterion of pain relief was considered as appropriate as described by individual authors.

A study was judged to be positive if the authors concluded that it was positive. If the authors concluded a study as negative, and there was a preponder- ance of evidence showing the positive nature of the study the conclusion was altered for the purposes of analysis of evidence.

\section{Results}

\section{Diagnostic Sacroiliac Joint Injections}

The diagnosis of symptomatic sacroiliac joint may mean that either sacroiliac joint structures or sacroiliac joint malfunctioning is responsible for pain. Thus far, a criterion standard for the diagnosis of painful lumbar sacroiliac joint has not been established. Standards used in the diagnosis of sacroiliac joint pain are diverse. IASP (11) has proposed criteria for making the diagnosis of sacroiliac joint pain:

- Pain is present in the region of the sacroiliac joint

- Stressing the sacroiliac joint by clinical tests that are selective for the joint reproduces the patient's pain.

- Selectively infiltrating the putatively symptomatic joint with local anesthetic completely relieves the patient of pain.

Multiple authors have used different criteria. Fortin et al (30) used patterns of pain distribution, prov-

Table 1. Designation of levels of evidence

\begin{tabular}{|l|l|}
\hline Level I & $\begin{array}{l}\text { Conclusive: Research-based evidence with multiple relevant and high-quality scientific studies or consistent reviews of } \\
\text { meta-analyses. }\end{array}$ \\
\hline Level II & $\begin{array}{l}\text { Strong: Research-based evidence from at least 1 properly designed randomized, controlled trial; or research-based } \\
\text { evidence from multiple properly designed studies of smaller size; or multiple low quality trials. }\end{array}$ \\
\hline Level III & $\begin{array}{l}\text { Moderate: } \\
\text { a) Evidence obtained from well-designed pseudorandomized controlled trials (alternate allocation or some other } \\
\text { method); } \\
\text { b) evidence obtained from comparative studies with concurrent controls and allocation not randomized (cohort } \\
\text { studies, case-controlled studies, or interrupted time series with a control group); } \\
\text { c) evidence obtained from comparative studies with historical control, two or more single-arm studies, or interrupted } \\
\text { time series without a parallel control group. }\end{array}$ \\
\hline Level IV & $\begin{array}{l}\text { Limited: Evidence from well-designed nonexperimental studies from more than 1 center or research group; or } \\
\text { conflicting evidence with inconsistent findings in multiple trials. }\end{array}$ \\
\hline Level V & $\begin{array}{l}\text { Indeterminate: Opinions of respected authorities, based on clinical evidence, descriptive studies, or reports of expert } \\
\text { committees. }\end{array}$ \\
\hline
\end{tabular}

Adapted from ref 6,90-92 
ocation of pain during sacroiliac joint injection, and a single anesthetic block. Schwarzer et al (33) used a single injection in patients with pain experienced below $L 5 / S 1$ and a $75 \%$ reduction in pain following injection of local anesthetic. Dreyfuss et al (40) used a single injection of local anesthetic and corticosteroid, noted pain provocation, and required more than $90 \%$ reduction in the main pain as distinct from a chance change in VAS assessment of pain generally. Slipman et al (32) used an $80 \%$ reduction in general pain VAS following single anesthetic injection in low back pain patients. In contrast, multiple authors used dual blocks with 2 local anesthetics of different duration of action $(8-10,34,36,50,51)$. Berthelot et al (54) evaluated provocative sacroiliac joint maneuvers and sacroiliac joint blocks and concluded that both are unreliable for diagnosing methodological quality sacroiliac joint pain.
The database search produced 1,670 articles of which 126 abstracts were selected for review for diagnostic interventions. Of these, 13 articles were reviewed $(8-10,33-36,50,51,54,82,83,93)$. Five were excluded because they were only single injection studies $(33,35,82,83,93)$. One study $(54)$ was excluded as this was a review of multiple other studies. The remaining 7 were chosen for inclusion in the analysis (8$10,34,36,50,51)$. Of these, there were 4 publications from 2 studies $(34,36,50,51)$. All 5 studies were performed under fluoroscopic guidance and employed a comparative, controlled local anesthetic technique. All 5 used a screening lidocaine injection followed by a confirmatory bupivacaine injection in those patients who had a positive response.

Descriptive Characteristics of Prevalance Studies

The description of included studies along with

Table 2. Characteristics of reported prospective diagnostic studies evaluating prevalence

\begin{tabular}{|c|c|c|c|c|}
\hline Study & Participants & Objective(s) & Interventions(s) & Result(s) \\
\hline $\begin{array}{l}\text { Maigne et al (8) } \\
\text { AHRQ score: } 3 / 5 \\
\text { QUADAS score: } 10 / 14\end{array}$ & $\begin{array}{l}54 \text { patients aged } \\
18-75 \text { with chronic } \\
\text { unilateral LBP with } \\
\text { or without radiation } \\
\text { to the posterior } \\
\text { thigh for }>50 \\
\text { days (median } 4.2 \\
\text { months). Patients } \\
\text { had failed epidural } \\
\text { or lumbar facet } \\
\text { injections. }\end{array}$ & $\begin{array}{l}\text { To determine } \\
\text { the prevalence of } \\
\text { sacroiliac joint } \\
\text { pain in a selected } \\
\text { population of } \\
\text { patients with low } \\
\text { back pain and } \\
\text { assess certain pain } \\
\text { provocation tests. }\end{array}$ & $\begin{array}{l}\text { Successful blockade of the } \\
\text { sacroiliac joint in } 54 \text { patients. A } \\
\text { screening block was done with } 2 \% \\
\text { lidocaine and a confirmatory block } \\
\text { was performed with bupivacaine } \\
0.5 \% \text {. Greater than } 75 \% \text { relief was } \\
\text { considered a positive block. }\end{array}$ & $\begin{array}{l}\text { Prevalence }=18.5 \% \\
\text { False-positive rate } \\
=20 \%\end{array}$ \\
\hline $\begin{array}{l}\text { Manchikanti et } \\
\text { al (9) } \\
\text { AHRQ score: } 4 / 5 \\
\text { QUADAS score: } 11 / 14\end{array}$ & $\begin{array}{l}120 \text { patients (age } \\
18-90 \text { ) presenting } \\
\text { to the clinic with } \\
>6 \text { months of } \\
\text { low back pain } \\
\text { and no structural } \\
\text { basis for the pain } \\
\text { by radiographic } \\
\text { imaging. } 20 \text { patients } \\
\text { were evaluated for SI } \\
\text { joint pain. }\end{array}$ & $\begin{array}{l}\text { To determine } \\
\text { the frequency of } \\
\text { various structures } \\
\text { responsible for low } \\
\text { back pain. }\end{array}$ & $\begin{array}{l}\text { All patients had facet blocks. } \\
\text { Nonresponders who fit criteria had } \\
\text { double injection SIJ blocks. The } \\
\text { screening block was done with } 2 \% \\
\text { lidocaine and the confirmatory } \\
\text { block was performed using } 0.5 \% \\
\text { bupivacaine. }\end{array}$ & $\begin{array}{l}\text { The incidence of } \\
\text { SIJ pain was } 2 \% \text { of } \\
\text { the overall sample } \\
\text { and } 10 \% \text { of those } \\
\text { suspected to have } \\
\text { SIJ pain. The false- } \\
\text { positive rate was } \\
22 \% \text {. }\end{array}$ \\
\hline $\begin{array}{l}\text { Irwin et al (10) } \\
\text { AHRQ score: } 3 / 5 \\
\text { QUADAS score: 7/14 }\end{array}$ & $\begin{array}{l}158 \text { patients } \\
\text { underwent sacroiliac } \\
\text { joint injections with } \\
\text { average symptoms } \\
\text { duration of } 34 \\
\text { months. Patients } \\
\text { failed conservative } \\
\text { modalities prior to } \\
\text { injection therapy. }\end{array}$ & $\begin{array}{l}\text { To evaluate } \\
\text { prevalence and } \\
\text { correlation between } \\
\text { age, gender, and } \\
\text { body mass index by } \\
\text { dual comparative } \\
\text { local anesthetic } \\
\text { blocks. }\end{array}$ & $\begin{array}{l}\text { The fluoroscopically guided } \\
\text { contrast-enhanced sacroiliac joint } \\
\text { injections were performed initially } \\
\text { with } 2 \mathrm{~mL} \text { of } 2 \% \text { lidocaine for } \\
\text { the first injection, followed by } 2 \\
\text { mL of } 0.25 \% \text { bupivacaine, a local } \\
\text { anesthetic, for the confirmatory } \\
\text { injection. A patient was required } \\
\text { to have at least } 70 \% \text { reduction of } \\
\text { familiar painful symptoms after the } \\
\text { initial injection for } 3 \text { or } 4 \text { hours for } \\
\text { positive response. }\end{array}$ & $\begin{array}{l}26.6 \% \text { were found } \\
\text { to have sacroiliac } \\
\text { joint pain by dual } \\
\text { injections. }\end{array}$ \\
\hline
\end{tabular}


methodologic quality criteria are illustrated in Table 2 .

Maigne et al (8) studied 67 patients who had chronic ( $>50$ days) unilateral low back pain (VAS $>4$ ) with or without radiation to the posterior thigh with associated pain and tenderness over the posterior sacroiliac joint. The block was successful in 54 patients. Double injections were performed with a screening diagnostic lidocaine injection $(2 \mathrm{ml})$ performed first. Relief of $>75 \%$ relief was considered a positive result. Nineteen of 54 patients had $>75 \%$ relief from the screening block and 10 of 19 participants had $>75 \%$ improvement from the confirmatory block. Of the 54,10 or $18.5 \%$ were considered to have sacroiliac joint pain. False-positive rate was determined as $20 \%$ (83). As only patients with a high likelihood of sacroiliac joint pain were included in the study, no determination of the prevalence of sacroiliac joint pain can be made.

Manchikanti et al (9) evaluated 120 patients that presented to the pain clinic with low back pain for $>6$ months. All of the participants initially had facet blocks and were negative for facet joint pain. Patients without facet joint pain, but with suspected sacroiliac joint involvement (pain in the sacral region, sacroiliac joint tenderness and positive provocative maneuvers) had a sacroiliac joint injection. They had screening sacroiliac joint injections with $2 \%$ lidocaine followed in 3 to 4 weeks by confirmatory bupivacaine blocks. Twenty of 120 patients had sacroiliac joint injections and 6 of 20 patients had a positive response to the screening block. Of those 6 patients, 2 had a positive response to the confirmatory bupivacaine block resulting in a $10 \%$ prevalence of sacroiliac joint pain. A definite or positive response was defined as $>80 \%$ relief of pain.

Irwin et al (10) evaluated the prevalence and correlation between age, gender, and body mass index as they relate to sacroiliac joint pathology diagnosed by dual comparative local anesthetic blocks. A retrospective chart review of 190 consecutive patients who had received sacroiliac joint injection evaluated at a multidisciplinary academic spine center between August 2001 and August 2004 with a chief complaint of low back/leg and/or sacroiliac pain was performed. Of those, 158 patients were included in the study population with exclusion of 33 patients. Fluoroscopic guided injections were performed utilizing $2 \mathrm{~mL}$ of $2 \%$ lidocaine for the first injection and $2 \mathrm{~mL}$ of $0.25 \%$ bupivacaine for the confirmatory injection. They also used $80 \mathrm{mg}$ of depomethylprednisolone or $6 \mathrm{mg}$ of Celestone Soluspan with bupivacaine. A patient was required to have at least $70 \%$ reduction of familiar painful symptoms after the initial injection for 3 hours to be considered for the confirmatory injection. A 70\% reduction in familiar painful symptoms for more than 4 hours was also required after the second injection to be considered as having a positive diagnosis of sacroiliac joint pathology. All injections were performed by one physician. The percentage of patients diagnosed with sacroiliac joint pain by dual comparative local anesthetic injection was $26.6 \%(42 / 158)$. They concluded that patients who were positive for sacroiliac joint pain tend to be older than those without, whereas, gender, age, and smoking status were not found to correlate with sacroiliac joint pathology.

Accuracy

Sacroiliac joint blocks have been shown to have face validity. Low volum es of local anesthetic selectively injected into the target joint after contrast verification of the needle position may anesthetize the joint. Appropriate precautions need to be observed to ensure there is no extravasation to adjacent structures $(2,84,94-96)$. The value and validity of controlled comparative local anesthetic blocks has been described and demonstrated (84,97-103), even though some have questioned the validity of controlled blocks (104-107).

Sacroiliac joint blocks also have been shown to have construct validity. However, to have construct validity, sacroiliac joint blocks must be controlled. Single diagnostic blocks carry a false-positive rate of $20 \%$ (8) and $22 \%$ (9). Patients are liable to report relief of pain after a diagnostic block for reasons other than the pharmacological action of drug administration (97). Consequently, it is imperative to know in every individual case whether the response is a true positive (84). The validity of controlled comparative local anesthetic blocks for facet joint diagnostic blocks was confirmed with placebo controlled diagnostic blocks $(97,98)$.

Controlled comparative local anesthetic blocks have been described as the gold standard, and the analgesic response to a properly performed diagnostic block as the most reliable method to diagnose sacroiliac joint pain. However, the validity of intraarticular sacroiliac joint blocks remains unproven (2). There are many factors that can impact on the sensitivity and specificity of diagnostic blocks, specifically the sacroiliac joint blocks. These include the placebo effect, convergence and referred pain, neuroplasticity and central sensitization, expectation bias, unintentional sympathetic blockade, systemic absorption of local anesthetic, and psychosocial issues (2). In addition, sacro- 
iliac joint can be one of the most challenging spinal injection procedures. Extravasation of local anesthetic to surround pain-generating structures such as muscles, ligaments, and lumbosacral nerve roots can lead to false-positive blocks. Conversely, failure to obtain adequate local anesthetic spread to the anterior and cephalad portions of the sacroiliac joint can result in false-negative blocks. North et al (104) examined the specificity and sensitivity of a battery of lumbosacral local anesthetic blocks in 33 patients with a chief complaint of sciatica. They found that the specificity of all blocks was exceedingly low; however sacroiliac joint blocks were not performed in this study. Fortin et al (30) reported extravasation of contrast with injection of mean volume of $1.6 \mathrm{~mL}$ in 9 of 10 asymptomatic subjects during sacroiliac joint injection, with half having at least moderate spread outside the joint. After the injection of local anesthetic, $40 \%$ of the subjects noted lower extremity numbness, indicating inadvertent anesthetization of the lumbosacral nerve roots. Maigne et al (8) excluded 3 of the initial 67 patients because of "sciatic palsy" after the screening block and another 7 were excluded because penetration of the sacroiliac joint was impossible. van der Wurff $(50,51)$ reported leakage of anesthetic fluid, mostly due to a ventral position of the needle, occurred in 5 patients, resulting in a temporary sciatic palsy. Fortin et al (108) showed that sacroiliac joint can cause sciatic symptoms. Other authors $(33,34,40,94)$ reported less frequent failure rates with fluoroscopically guided sacroiliac joint injections in the range of $5 \%$. Technical difficulties may be more frequently encountered in elderly patients and those with spinal arthropathies in whom degenerative changes are more pronounced. Sacroiliac joint injections have been performed by fluoroscopy, CT, ultrasound, and even MRI guidance (109). While some feel that CT guidance may be superior to fluoroscopy, there is no documented comparisons of all the various imaging modalities for sacroiliac joint injections. Thus, no superiority can be claimed for CT or MRI over fluoroscopy. However, it is confirmed that "blind" injections are unlikely to be intraarticular.

Rosenburg et al (95) reported in a double-blind study of 39 joints in 37 patients, intraarticular injection was accomplished in only 22 of the patients whereas sacral foraminal spread occurred $44 \%$ of the time without fluoroscopy. In 3 patients, no contrast was seen on CT scanning, indicating probable vascular uptake. In $24 \%$ of injections, contrast extended into the epidural space.
Hansen (96) evaluated the necessity of fluoroscopy for sacroiliac joint injections. In an evaluation, 60 patients undergoing sacroiliac joint injections, were placed blindly then examined under fluoroscopy for accurate needle placement. Results of blind needle placement revealed that only 5 of 60 patients were felt to have needle placement approximating a therapeutic point of contact with the sacroiliac joint. In addition, the posterior superior iliac spine was found to be a poor indicator of sacroiliac joint anatomic access. They concluded that based on this study, accurate placement of sacroiliac joint injections is successful without fluoroscopy in only $12 \%$ of the patients, even in experienced hands.

\section{Prevalence}

This review led to the inclusion of 3 studies (810) utilizing controlled local anesthetic blocks. Three studies were excluded $(33,83,93)$. Schwarzer et al (33) utilized a single local anesthetic block with a reported prevalence of $30 \%$. Pang et al (93) also utilized single block with a prevalence report of $10 \%$ of chronic low back pain patients. Maigne and Planchon (83) studied the prevalence of sacroiliac joint pain after lumbar fusion utilizing single local anesthetic blocks with a prevalence of $35 \%$. Thus, all 3 studies were excluded.

Maigne et al (8), even though utilizing a double block paradigm that validated the diagnostic ability of the test with false-positive rates, failed to provide the prevalence rate in chronic spinal pain populations, as it was performed in a select group of patients with suspicion of sacroiliac joint pain. Manchikanti et al (9) showed a low prevalence of sacroiliac joint pain with a double block paradigm. The study was performed in patients suffering with low back pain, negative for other sources of pain. Twenty patients had sacroiliac joint injections and 2 of 20 patients had a positive response to confirmatory bupivacaine block resulting in a $2 \%$ overall prevalence of sacroiliac joint pain and $10 \%$ in suspected population. Irwin et al (10) in a retrospective review of 158 patients undergoing sacroiliac joint injections showed a prevalence rate of $26.6 \%$.

Even though short-term relief from sacroiliac joint injection is considered as a gold standard for the diagnosis of sacroiliac joint pain, there was no blinded comparison of the test or reference standard in evaluation of these investigations.

Cost effectiveness.

There have not been any cost effectiveness studies performed in evaluation of the diagnostic utility of 
Table 3. Studies assessing the accuracy of history and physical examination in the diagnosis of sacroiliac (SI) joint pain confirmed by local anesthetic block

\begin{tabular}{|c|c|c|c|c|c|}
\hline Author(s) & Study type & Patients & $\begin{array}{c}\text { Diagnostic } \\
\text { standard }\end{array}$ & Results & Comments \\
\hline $\begin{array}{l}\text { Schwarzer et } \\
\text { al, } 1995 \\
(33)\end{array}$ & $\begin{array}{l}\text { Cross-sectional, } \\
\text { analytic study }\end{array}$ & $\begin{array}{l}43 \text { pts with chronic } \\
\text { axial LBP principally } \\
\text { below L5-S1. }\end{array}$ & $\begin{array}{l}\text { Used }>75 \% \\
\text { pain relief to a } \\
\text { single block as } \mathrm{dx} \\
\text { criteria. }\end{array}$ & $\begin{array}{l}\text { No PE test was of } \\
\text { predictive value in } \\
\text { predicting subsequent } \\
\text { response to block. Only } \\
\text { groin pain found to } \\
\text { be more common in } \\
\text { pts with (+) diagnosed } \\
\text { block. }\end{array}$ & $\begin{array}{l}30 \% \text { of pts diagnosed } \\
\text { with SI jt pain } \\
\text { based on diagnosis } \\
\text { block, } 21 \% \text { based on } \\
\text { response to block } \\
\text { and ventral capsular } \\
\text { tear on CT scanning, } \\
\text { and } 16 \% \text { based on } \\
\text { response to block, } \\
\text { capsular tear and } \\
\text { pain provocation. }\end{array}$ \\
\hline $\begin{array}{l}\text { Dreyfuss et } \\
\text { al, } 1996 \\
(40)\end{array}$ & $\begin{array}{l}\text { Prospective } \\
\text { study assessing } \\
\text { value of history } \\
\text { and physicial } \\
\text { examination. }\end{array}$ & $\begin{array}{l}85 \text { pts with axial LBP } \\
\text { principally below L5. }\end{array}$ & $\begin{array}{l}\text { Used }>90 \% \text { pain } \\
\text { relief to a single } \\
\text { SI joint block } \\
\text { as criteria for } \\
\text { diagnosis. }\end{array}$ & $\begin{array}{l}45 \text { pts had a (+) block, } \\
40 \text { a (-) block. No } \\
\text { historical or physical } \\
\text { examination finding } \\
\text { predicted response to } \\
\text { block. }\end{array}$ & $\begin{array}{l}\text { Response to } \\
\text { previous therapy not } \\
\text { indicative of SI joint } \\
\text { pain. }\end{array}$ \\
\hline $\begin{array}{l}\text { Maigne et al, } \\
1996 \\
(8)\end{array}$ & $\begin{array}{l}\text { Prospective study } \\
\text { assessing the } \\
\text { prevalence of SI } \\
\text { joint pain using } \\
\text { double blocks and } \\
\text { the accuracy of } \\
\text { pain. Provocation } \\
\text { tests to dx the } \\
\text { disorder. }\end{array}$ & $\begin{array}{l}67 \text { pts with chronic } \\
\text { unilateral LBP } \\
\text { without extension } \\
\text { below the knee. }\end{array}$ & $\begin{array}{l}\text { Criteria for } \\
\text { diagnosis was }> \\
75 \% \text { pain relief } \\
\text { after lidocaine } \\
\text { screening block } \\
\text { followed by } \\
\text { similar pain relief } \\
\text { lasting }>2 \text { hours } \\
\text { after confirmatory } \\
\text { bupivacaine block. }\end{array}$ & $\begin{array}{l}\text { Of } 54 \text { pts completing the } \\
\text { study, } 19 \text { experienced } \\
\text { good pain relief with the } \\
\text { screening block, and } 10 \\
\text { of these ( } 18.5 \%) \text { rec'd > } \\
2 \text { hours pain relief after } \\
\text { the confirmatory block. }\end{array}$ & $\begin{array}{l}\text { There was no } \\
\text { association between } \\
\text { any clinical variable } \\
\text { or pain provocation } \\
\text { test and a (+) } \\
\text { response to both } \\
\text { blocks. }\end{array}$ \\
\hline $\begin{array}{l}\text { Broadhurst } \\
\text { and Bond, } \\
1998 \text { (45) }\end{array}$ & $\begin{array}{l}\text { Double- } \\
\text { blind study } \\
\text { determining the } \\
\text { value of Patrick's } \\
\text { (FABER) test, } \\
\text { posterior shear } \\
\text { test and resisted } \\
\text { abduction } \\
\text { diagnosis. }\end{array}$ & $\begin{array}{l}40 \text { pts with LBP and } \\
\text { pain reproduction } \\
\text { using the } 3 \mathrm{PE} \text { tests. }\end{array}$ & $\begin{array}{l}\text { All pts had either } \\
\text { saline or } 1 \% \\
\text { lidocaine injected } \\
\text { into SI joint. } \\
\text { Diagnosis based } \\
\text { on }>70 \% \text { pain } \\
\text { reduction when } \\
\text { provocative test } \\
\text { performed. }\end{array}$ & $\begin{array}{l}\text { Patrick's test found to } \\
\text { have } 77 \% \text { sensitivity } \\
\text { and } 100 \% \text { specificity; } \\
\text { posterior shear test } \\
\text { had } 80 \% \text { sensitivity } \\
\text { and } 100 \% \text { specificity; } \\
\text { resisted abduction had } \\
87 \% \text { sensitivity and } \\
100 \% \text { specificity. }\end{array}$ & $\begin{array}{l}\text { No pt had }>70 \% \\
\text { pain reduction after } \\
\text { saline injection. }\end{array}$ \\
\hline $\begin{array}{l}\text { Slipman et } \\
\text { al, } 1998 \\
(44)\end{array}$ & $\begin{array}{l}\text { Prospective } \\
\text { cohort study } \\
\text { assessing } \\
\text { predictive value } \\
\text { of provocative } \\
\text { tests in dx SI joint } \\
\text { pain. }\end{array}$ & $\begin{array}{l}50 \text { pts without } \\
\text { spondyloarthropathy } \\
\text { who had (+) response } \\
\text { to } 3 \mathrm{dx} \text {. This was } \\
\text { completed as per } \\
\text { Ambulatory Surgery } \\
\text { Center format tests. }\end{array}$ & $\begin{array}{l}\text { Used }>80 \% \text { pain } \\
\text { relief to a single } \\
\text { block as criteria } \\
\text { for dx. }\end{array}$ & $\begin{array}{l}\text { SI jt blocks were }(+) \\
\text { in } 30 \text { pts for a positive } \\
\text { predictive value of } 60 \% \text {. } \\
\text { Steroid added to dx } \\
\text { block, with average } \\
\text { symptom reduction } \\
\text { being } 30.5 \%\end{array}$ & $\begin{array}{l}2 \text { of } 3(+) \text { diagnosis } \\
\text { tests had to be } \\
\text { Patrick's test and } \\
\text { sacral sulcus } \\
\text { tenderness. . }\end{array}$ \\
\hline $\begin{array}{l}\text { Young et al, } \\
2003 \\
(35)\end{array}$ & $\begin{array}{l}\text { Prospective } \\
\text { validity study } \\
\text { to identify } \\
\text { association } \\
\text { between PE \& } \\
\text { facet, discogenic, } \\
\text { and SI jt pain. }\end{array}$ & $\begin{array}{l}55 \text { of } 102 \text { pts with } \\
\text { chronic axial LBP } \\
\text { underwent SI joint } \\
\text { blocks. }\end{array}$ & $\begin{array}{l}\text { Used not only pain } \\
\text { relief }(>80 \%) \text { to a } \\
\text { single block as dx } \\
\text { criteria, but also } \\
\text { concordant pain } \\
\text { provocation. }\end{array}$ & $\begin{array}{l}22 \text { of } 57 \text { injected joints } \\
\text { had }(+) \text { response to SI } \\
\text { jt block. Pts with SI jt } \\
\text { pain rarely had midline } \\
\text { LBP or pain above L5. } \\
\text { Positive correlation } \\
\text { noted between SI jt } \\
\text { pain and increased } \\
\text { pain when rising from } \\
\text { sitting, unilateral pain } \\
\text { and }>3 \text { positive pain } \\
\text { provocation tests. }\end{array}$ & $\begin{array}{l}5 \text { provocation tests } \\
\text { used to examine } \\
\text { the SI joint. Clinical } \\
\text { evaluation done by } \\
\text { physical therapists. } \\
\text { Also sought to } \\
\text { identify clinical } \\
\text { determinates of } \\
\text { discogenic LBP and } \\
\text { lumbar facet pain. }\end{array}$ \\
\hline
\end{tabular}


Table 3 Continued. Studies assessing the accuracy of history and physical examination in the diagnosis of sacroiliac (SI) joint pain confirmed by local anesthetic block

\begin{tabular}{||l|l|l|l|l|l|}
\hline Author(s) & \multicolumn{1}{|c|}{ Study type } & \multicolumn{1}{|c|}{ Patients } & \multicolumn{1}{c|}{$\begin{array}{c}\text { Diagnostic } \\
\text { standard }\end{array}$} & \multicolumn{1}{|c|}{ Results } & \multicolumn{1}{c|}{ Comments } \\
\hline $\begin{array}{l}\text { Van der } \\
\text { wurff et al } \\
2006(51)\end{array}$ & $\begin{array}{l}\text { Prospective, } \\
\text { observational } \\
\text { study. }\end{array}$ & $\begin{array}{l}\text { A total of } 140 \text { patients } \\
\text { with chronic low back } \\
\text { pain visited the pain } \\
\text { clinic. } 60 \text { patients } \\
\text { entered the study. }\end{array}$ & $\begin{array}{l}\text { A reduction in } \\
\text { the patients pain } \\
\text { of 50\% or more } \\
\text { for at least } 1 \text { hour } \\
\text { for short-acting } \\
\text { local anesthetic } \\
\text { or 4 hours for } \\
\text { long-acting local } \\
\text { anesthetic. }\end{array}$ & $\begin{array}{l}\text { 27 patients responded } \\
\text { positively to the blocks, } \\
\text { of whom 23 were } \\
\text { found positive after the } \\
\text { multiple test regimen } \\
\text { and 4 were negative. }\end{array}$ & $\begin{array}{l}\text { The test regimen } \\
\text { with 3 or more } \\
\text { positive tests } \\
\text { is indicative of } \\
\text { sacroiliac joint pain. }\end{array}$ \\
\hline $\begin{array}{l}\text { Laslett et al } \\
2003 \& 2005 \\
(34,36)\end{array}$ & $\begin{array}{l}\text { A blinded } \\
\text { concurrent } \\
\text { criteria-related } \\
\text { validity design } \\
\text { study. }\end{array}$ & $\begin{array}{l}\text { 48 patients with } \\
\text { chronic lumbopelvic } \\
\text { referred to diagnostic } \\
\text { spinal injection } \\
\text { procedures. }\end{array}$ & $\begin{array}{l}\text { Comparative } \\
\text { controlled } \\
\text { local anesthetic } \\
\text { blocks with } 80 \% \\
\text { reduction in pain } \\
\text { for the duration of } \\
\text { anesthetic effect. }\end{array}$ & $\begin{array}{l}\text { 10 of 11 sacroiliac } \\
\text { patients met clinical } \\
\text { examination criteria } \\
\text { for having sacroiliac } \\
\text { joint pain, sensitivity, } \\
\text { specificity, and positive } \\
\text { likelihood ratios. }\end{array}$ & $\begin{array}{l}\text { The diagnostic } \\
\text { accuracy of the } \\
\text { clinical examination } \\
\text { and reasoning } \\
\text { process was superior } \\
\text { to the sacroiliac joint } \\
\text { pain provocation } \\
\text { tests alone. }\end{array}$ \\
\hline
\end{tabular}

$H x=$ history $; J=$ joint $; P E=$ physical examination $; L B P=$ low back pain $;$ pts = patients; $C T=$ computed tomography $;$ b $/ c=$ because $;$ SI = sacroiliac.

sacroiliac joint blocks.

Level of Evidence:

The evidence for the specificity and validity of diagnostic sacroiliac joint injections is moderate.

\section{Validation of Provocation Tests}

Tests validated with a local anesthetic block. in this evaluation data provided by authors of 8 different studies $(8,33-35,40,44,45,51)$ was utilized. Table 3 illustrates characteristics of various provocation tests. Simpson and Gemmell (67) performed a systematic review to critically appraise the literature on the accuracy of multiple tests used for the evaluation of the spine, utilizing QUADAS criteria. They included 5 studies that met the inclusion criteria for identifying sacroiliac joint pain $(34,39,40,45,56)$.

Berthelot et al (54) evaluated reliability of provocative sacroiliac joint maneuvers and dual sacroiliac joint blocks in the diagnosis of sacroiliac joint pain. They concluded that clinical signs and maneuvers are unreliable for diagnosing pain originating in the sacroiliac joint, as they have low sensitivity and specificity. In addition, they also added that the sacroiliac joint block is similarly unreliable. They also added that pain patterns believed to have their source within the sacroiliac joint can be related to extra-articular structures, most notably the numerous ligaments surrounding the sacroiliac joint. Consequently, they believed that this finding may have a positive impact on the diagnosis and treatment of low back pain and buttock pain, facilitating injections into selected iliolumbar ligaments which can provide dramatic improvements in patients with atypical sacroiliac joint pain. They also felt that sacroiliac joint arthrodesis and glucocorticoid injections into the sacroiliac joint may provide pain relief in many patients with pain originating in the neighboring ligaments, with the longer duration of action of glucocorticoids ensuring better diffusion into the ligaments around the sacroiliac joint, as compared to anesthetic agents.

Laslett et al (34) suggested that due to the large size and lack of mobility of the sacroiliac joints, a large amount of force has to be exerted in the correct direction to adequately stress the structures. This is a potential source for false-negative. Also, if the stress is applied to the incorrect location, the sacroiliac joint may not be stressed and pain may arise from other tissues resulting in false-positives. The clinician must also remember that the clinical examination may not be able to clearly diagnose a condition due to illness behaviors, severe pain, body size, structure, and shape (67).

Broadhurst and Bond (45) also mentioned that the force needed to stress the sacroiliac joint is large and may strain surrounding tissues and joints such as the lumbar facet joints. They also mentioned that the force needed to stress the sacroiliac joint is large and may strain surrounding tissues and joints such as the lum- 
bar facet joints and the sacrospinous, interosseous, and iliolumbar ligaments, resulting in false-positives. However, both Laslett et al (34) and Broadhurst and Bond (45) claimed that the commonly used tests for sacroiliac joint dysfunction do have diagnostic value, especially when used in the context of specific clinical reasoning. Conversely, Dreyfuss et al (40) found tests that are commonly used to detect sacroiliac joint involvement to be of no diagnostic value on the basis of a $90 \%$ reduction in pain following an intraarticular block.

Laslett et al (36) examined the diagnostic power of pain provocation of sacroiliac joint tests singly and in various combinations, in relation to an accepted criterion standard. In a blinded criterion-related validity design, 48 patients were examined by physiotherapists using pain provocation sacroiliac joint tests and received an injection of local anesthetic into the sacroiliac joint. The tests (compression, distraction, thigh thrust, Gaenslen, and sacral thrust) were evaluated singly and in various combinations for diagnostic power. All patients with a positive response to diagnostic injection reported pain with at least one sacroiliac joint test. Sensitivity and specificity for 3 or more of 6 positive sacroiliac joint tests were $94 \%$ and $78 \%$, respectively. They concluded that composites of provocation sacroiliac joint tests are of value in clinical diagnosis of symptomatic sacroiliac joint. Three or more out of 6 tests or any of 2 of 4 selected tests have the best predictive power in relation to the results of intraarticular anesthetic block injections. When all 6 provocation tests do not provoke familiar pain, the sacroiliac joint can be ruled out as a source of current low back pain.

Young et al (35) in a prospective validity study to identify association between provocative maneuvers and sacroiliac joint pain, injected 55 of 102 patients with sacroiliac joint blocks. However, they used a single block diagnostic criteria, along with concordant pain provocation. Twenty of 57 injected joints had positive response to sacroiliac joint block. Patients with sacroiliac joint pain rarely had midline low back pain or pain above L5. Positive correlation noted between sacroiliac joint pain and increased pain when rising from sitting, unilateral pain, and greater than 3 positive pain provocation tests. Table 3 illustrates studies assessing accuracy of history and physical examination in the diagnosis of sacroiliac joint pain confirmed by local anesthetic injections. The compression test, also known as midline sacral thrust, is reported to stretch the posterior ligaments and capsule dorsally over the reference and compress the anterior part of the joint (68). The test is considered positive if pain is elicited in the sacroiliac joint, or gluteal region. Laslett (37) and Laslett and Williams (38) found good interexaminer reliability utilizing 7 pain provocation tests for sacroiliac joint dysfunction in 51 patients with low back pain. However, the majority of published studies indicate significant variability of the inter-examiner reliability for this test. Potter and Rothstein (59) found a $70 \%$ inter-tester reproducibility, while Strender et al (60) noted a poor kappa coefficient (0.26) for this test. However, neither of these studies addressed sensitivity or specificity, controls were not evaluated, and subjects did not have validated sacroiliac joint pathology. van der wurff $(48,49)$ calculated the sensitivity of the compression test to be $19 \%$ based on one study (61), $0 \%$ based upon another study (64), and $7 \%$ based on a different study (62). The specificity was calculated and was shown to be $100 \%$ based on a different study (64) and $90 \%$ based on another study (62).

van der wurff (51) using 5 sacroiliac joint pain provocation tests, namely Distraction test, Compression test, thigh thrust test, Patrick's sign, Gaenslen's test found that a regimen with 3 or more positive tests is indicative of sacroiliac joint pain. Robinson et al (53) assessed the inter-rater reliability of one palpation of the 6 pain provocation tests for pain of sacroiliac origin. Clusters out of 3 and 5 pain provocation tests were found to be reliable. Tong et al (58) also evaluated the inter-examiner reliability of 3 methods of combining test results to determine the side of sacral restriction, sacral base position and innominate bone position and concluded that using the results of the most reliable examination consistently has the best inter-examiner reliability.

Cost effectiveness.

There are no studies evaluating cost effectiveness of utilizing provocation tests in the diagnosis of sacroiliac joint pain.

Level of Evidence:

The evidence for accuracy of provocative maneuvers in diagnosis of sacroiliac joint injections pain is limited.

\section{Description of Provocation Studies}

Distraction or gapping test is reported to stretch the anterior ligaments and capsule ventrally and compresses the posterior part of the joint $(63,68)$. If lumbar pain is elicited, support is placed at the low back to rule out lumbar involvement. The test is positive if 
Table 4. Common tests utilized in evaluation of sacroiliac joint dysfunction

\begin{tabular}{|c|c|}
\hline $\begin{array}{l}\text { Compression Test (midline sacral } \\
\text { thrust) }\end{array}$ & $\begin{array}{l}\text { The examiner places both hands on the patient's ASIS and exerts a medial force } \\
\text { bilaterally to implement the test. The compression test is more frequently performed } \\
\text { with the patient in the side-lying position. The examiner stands behind the patient with } \\
\text { their elbows locked in extension and palms interlocked over the anterolateral or upper } \\
\text { part of the patient's iliac crest. The examiner exerts a medial or downward force towards } \\
\text { the floor. }\end{array}$ \\
\hline Distraction or Gapping Test & $\begin{array}{l}\text { The gapping test, also known as the distraction test, is performed with the patient in a } \\
\text { supine position. The examiner places the heel of both hands at the same on each ASIS, } \\
\text { pressing downward and laterally. }\end{array}$ \\
\hline Patrick (FABERE) Test & $\begin{array}{l}\text { With the patient supine on a level surface, the thigh is flexed and the ankle is placed } \\
\text { above the patella of the opposite extended leg. With the knee depressed and the ankle } \\
\text { maintaining its position above the opposite knee, the patient will complain of pain } \\
\text { before the knee reaches the level obtained in normal persons. }\end{array}$ \\
\hline Gaenslen's Test & $\begin{array}{l}\text { The patient lies supine, flexes the ipsilateral knee and hip with the thigh crowded } \\
\text { against the abdomen with the aid of both the patient's hands clasped about the flexed } \\
\text { knee. This brings the lumbar spine firmly in contact with the table and fixes both } \\
\text { the pelvis and lumbar spine. The patient is then brought well to the side of the table, } \\
\text { and the opposite thigh is slowly hyperextended with gradually increasing force by } \\
\text { pressure of the examiner's hand on the top of the knee. With the opposite hand, the } \\
\text { examiner assists the patient in fixing the lumbar spine and pelvis by pressure over the } \\
\text { patient's clasped hands. The hyperextension of the hip exerts a rotating force on the } \\
\text { corresponding half of the pelvis in the sagittal plane through the transverse axis of the } \\
\text { sacroiliac joint. The rotating force causes abnormal mobility accompanied by pain, } \\
\text { either local or referred on the side of the lesion. }\end{array}$ \\
\hline $\begin{array}{l}\text { Shear Test (Cranial Shear Test or } \\
\text { Midline Sacral Thrust) }\end{array}$ & $\begin{array}{l}\text { This test consists of the patient lying in the prone position and the examiner applies } \\
\text { a pressure to the sacrum near the coccygeal end, directed cranially. The ilium is held } \\
\text { immobile through the hip joint as the examiner applies counter pressure against legs } \\
\text { in the form of traction force - directed caudad. The test is considered positive if the } \\
\text { maneuver aggravates the patient's typical pain. }\end{array}$ \\
\hline Fortin Finger Test & $\begin{array}{l}\text { The subject is asked to point to the region of pain with one finger. Positive sign was if } \\
\text { the patient can localize the pain with one finger, the area pointed to was immediately } \\
\text { inferomedial to the PSIS within } 1 \mathrm{~cm} \text {, and the patient consistently pointed to the same } \\
\text { over at least two trials. }\end{array}$ \\
\hline Gillet Test (One-leg Stork Test) & $\begin{array}{l}\text { This test is performed with the patient standing, facing away from the examiner, with } \\
\text { his feet approximately } 12 \text { inches apart. Once each PSIS is localized by the examiner's } \\
\text { thumbs, the patient is asked to stand on one leg while flexing the contralateral hip and } \\
\text { flexing his knee to his chest. }\end{array}$ \\
\hline
\end{tabular}

pain is described in the gluteal or posterior crural areas. The test was shown to have $94 \%(59)$ and $88 \%(37,38)$, inter-examiner agreement respectively, when the gapping test was used to diagnose sacroiliac joint dysfunction. The sensitivity for the gapping test has been documented to range only between $11 \%$ and $21 \%$, whereas the specificity ranged from $90 \%$ to $100 \%(48,49,62)$. Maigne et al (8) found no statistically significant association between the gapping test and those patients who had $75 \%$ or greater pain relief from fluoroscopically guided sacroiliac joint injections.
The Patrick (FABERE) test is more commonly known as the Fabere sign, an acronym for flexion, abduction, external rotation, and extension. The sensitivity of this test was low $(57 \%)(48,49,62)$ whereas others have reported $77 \%$ sensitivity and $100 \%$ specificity (45). However, Bogduk (46) questioned the methodology and accuracy of the injection technique by these authors (45).

Gaenslen's test is a diagnostic maneuver to differentiate between lumbosacral and sacroiliac lesions (110). There is limited research pertaining to the Gaenslen's maneuver in order to make strong conclu- 
sions, however, Dreyfuss et al $(40,41)$ determined that this test was $68 \%$ sensitive and $35 \%$ specific. However, the validity of this test was challenged by others (62).

The shear test also known as the cranial shear test or midline sacral thrust was shown to have over $80 \%$ inter-tester reliability $(37,38)$. However, Leboeuf (56) described its specificity as $20 \%$ with a false-positive rate of $41 \%$ when comparing asymptomatic with symptomatic subjects. Dreyfuss et al $(40,41)$ questioned the utility of this test. van der Wurff et al (51) concluded that there are numerous clinical tests to identify sacroiliac joint pain, but none is reliable or validated. Kokmeyer et al (57) found that a multi-test regimen of 5 pain provocation tests was reliable if 3 of 5 tests are positive.

Table 4 illustrates commonly performed tests.

\section{Radiological imaging}

Radiological imaging has not been found to be an accurate indicator of a painful sacrioliac joint. Puhakka et al $(80,81)$ performed 2 evaluations, one with MR imaging of the normal sacroiliac joint with correlation to histology and the second one with MRI abnormalities of the sacroiliac joints in early spondyloarthropathy with a 1-year follow-up study. They concluded that coronal MR imaging does not allow assessment of normal anatomy. But when there are variants, or abnormalities of the ventral and dorsal margins of the cartilaginous sacroiliac joint and in early spondyloarthropathy, MRI can detect significant inflammatory and destructive changes of the sacroiliac joints over a 1-year follow-up, in spite of minimal changes in the clinical parameters. However, the MRI changes and inflammatory activity are not detectable by CT and x-ray examinations. Thus, MRI may be a sensitive method, without risks, for early diagnosis and for following disease progression in spondyloarthropathy. Radiographic studies assist in determining anatomic integrity, but the sacral joint mimics many pain presentations, and reliable and corroborative findings are vague (78). A retrospective study (79) showed that CT scans were negative in $42 \%$ of symptomatic sacroiliac joints.

\section{Therapeutic Sacroiliac Joint Interventions}

Sacroiliac joint pain may be managed by intraarticular injections, or neurolysis of sacroiliac joint innervation.

\section{Intraarticular Blocks}

Our search criteria yielded 163 reports, and 38 reports describing the effectiveness of these interven- tions were reviewed. From these, 16 relevant evaluations were selected for review and evidence synthesis $(94,111-125)$. Of these, 4 studies were randomized $(111,112,114,119), 9$ were prospective evaluations $(113,115-118,120-123)$, and 3 were retrospective evaluations $(94,124,125)$.

\section{Methodological Quality}

Of the 4 randomized trials selected for review, the study by Luukkainen et al (111) was excluded due to lack of long-term follow-up, and injection was periarticular. The second study by Fischer et al (114) was excluded as they evaluated only children with spondyloarthropathy. A third randomized trial (119) with sero-negative spondyloarthropathy treated with periarticular injections was excluded. Consequently only one randomized trial (112) met inclusion criteria.

Among the 9 prospective evaluations $(113,115$ 118,120-123), 6 studies were excluded because they evaluated only patients with spondyloarthropathy rather than sacroiliac joint pain or low back pain $(113,115,117,118,120,121)$. One study (123) was excluded due to short-term pain relief report study by Pereira et al (122) met inclusion criteria.

Among the 3 retrospective evaluations $(94,124$, 125), 2 evaluations by Slipman et al (124), and Chakraverty et al (125) were included. The study (94) was excluded due to short-term follow up.

\section{Study Characteristics}

Table 5 shows the study characteristics of included reports of therapeutic intraarticular sacroiliac joint injections.

Maugars et al (112) performed a double-blind study in 10 patients; 13 articulations, suffering with painful sacroiliitis. Six sacroiliac joint injections were injected with steroid and 7 were placebo injections. At 1 month, 5 of 6 sacroiliac joints with corticosteroid, (in comparison to none of the 7 of the placebo group), described a relief of $>70 \%$. Patients with 6 out of the 7 sacroiliac joints of the placebo group and 2 patients from the corticosteroid group who either failed the first injection or whose pain returned, were reinjected with corticosteroid. At 1 month, 12 of 14 (86\%) had good results and patients were still significantly better at 3 months (62\%) and 6 months (58\%).

Pereira et al (122) in a prospective observational study evaluated 10 patients with sacrioliac joint pain of which 9 had bilateral sacroiliitis. They treated these patients with 21 injections with corticosteroid without local anesthetic. The results showed good to excellent pain relief in 8 of 10 patients lasting a mean of 13.5 
months. The 2 non-responders suffered from fibromyalgia and reactive depression. They used MRI to guide the injections. They also showed that subchondral marrow edema resolved on follow-up MRI, minimally in 3 patients, partially in 3 patients, and completely in 3 patients, with a sensitivity of of $57 \%$, and specificity of only $69 \%$.

Slipman et al (124), in a retrospective evaluation with independent clinical review, evaluated the use of fluoroscopically guided therapeutic sacroiliac joint injections in patients with sacroiliac joint syndrome. The symptom duration of this patient population was as early as 1.5 months prior to inclusion in the study with an average symptom duration of 20.6 months. They reported a significant reduction in Oswestry disability scores at the time of follow-up. Visual Analog Scale pain scores were reduced at the time of discharge and at follow-up. Work status was also significantly improved at the time of discharge and at follow-up. A trend toward less drug usage was observed. They concluded that fluoroscopically guided therapeutic sacroiliac joint injections are a clinically effective intervention in the treatment of patients with sacroiliac joint syndrome.

Chakravarty et al (125) in an audit of conservative management of chronic low back pain in a secondary care setting, evaluated the results of intraarticular sacroiliac joint injections with corticosteroid included in 33 patients. Selection criteria was patients averaging 40 years of age with a range of 70 to 74 years. There was a $50 \%$ global subject to improvement 1 day to 4 weeks after the injection, $9 \%$ improvement 4 weeks to 3 months later, and only $1 \%$ at 3 to 6 months.

Level of evidence

The evidence for intraarticular sacroiliac joint injections is limited.

Table 5. Study characteristics of included reports of therapeutic intraarticular sacroiliac joint injections

\begin{tabular}{|c|c|c|c|c|}
\hline Study & Participants & Intervention(s) & Outcome(s) & $\begin{array}{c}\text { Conclusions } \\
\text { Short-term relief }< \\
6 \text { weeks } \\
\text { Long-term relief }> \\
6 \text { weeks }\end{array}$ \\
\hline $\begin{array}{l}\text { Maugars et al } 1996(112) \\
\text { Randomized, controlled } \\
\text { trial } \\
\text { AHRQ score: } 6 / 10 \\
\text { Cochrane score: } 6 / 10\end{array}$ & $\begin{array}{l}10 \text { patients } / 13 \\
\text { articulations with } \\
\text { painful sacroiliitis. }\end{array}$ & $\begin{array}{l}\text { Sacroiliac joint injection } \\
\text { with steroids or placebo. }\end{array}$ & $\begin{array}{l}86 \% \text { of patients had a good } \\
\text { result at } 1 \text { month, } 62 \% \text { at } \\
3 \text { months, and } 58 \% \text { at } 6 \\
\text { months. }\end{array}$ & $\begin{array}{l}\text { Positive short-term } \\
\text { and long-term }\end{array}$ \\
\hline $\begin{array}{l}\text { Pereira et al } 2000(122) \\
\text { Perspective evaluation } \\
\text { AHRQ score: } 5 / 8\end{array}$ & $\begin{array}{l}10 \text { patients with } \\
\text { sacroiliitis of which } 9 \\
\text { of them had bilateral } \\
\text { sacroiliitis }\end{array}$ & $\begin{array}{l}10 \text { patients were treated } \\
\text { with } 21 \text { injections with } \\
\text { corticosteroid without } \\
\text { local anesthetic, under } \\
\text { MRI guidance. }\end{array}$ & $\begin{array}{l}\text { The results showed good to } \\
\text { excellent pain relief in } 8 \text { of } \\
10 \text { patients lasting a mean of } \\
13.5 \text { months. }\end{array}$ & $\begin{array}{l}\text { Positive short-term } \\
\text { and long-term }\end{array}$ \\
\hline $\begin{array}{l}\text { Chakravarty et al } 2004 \\
\text { (125) } \\
\text { Retrospective evaluation } \\
\text { AHRQ acore: } 4 / 8\end{array}$ & $\begin{array}{l}\text { An audit of } \\
\text { conservative } \\
\text { management of } \\
\text { chronic low back } \\
\text { pain in a secondary } \\
\text { case setting. }\end{array}$ & $\begin{array}{l}\text { Intraarticular sacroiliac } \\
\text { joint injections with } \\
\text { corticosteroids included } \\
33 \text { patients with an } \\
\text { average age of } 40 \text { years. }\end{array}$ & $\begin{array}{l}\text { There was } 50 \% \text { global } \\
\text { subjective improvement } \\
1 \text { day to } 4 \text { weeks after the } \\
\text { injection, } 9 \% \text { improvement } 4 \\
\text { weeks to } 3 \text { months later, and } \\
\text { only } 1 \% \text { at } 3 \text { to } 6 \text { months. }\end{array}$ & $\begin{array}{l}\text { Negative short-term } \\
\text { and long-term }\end{array}$ \\
\hline $\begin{array}{l}\text { Slipman et al } 2001 \text { (124) } \\
\text { Retrospective evaluation } \\
\text { AHRQ acore: } 6 / 8\end{array}$ & $\begin{array}{l}31 \text { patients were } \\
\text { included. Each } \\
\text { patient demonstrated } \\
\text { a positive response } \\
\text { to a fluoroscopically } \\
\text { guided diagnostic } \\
\text { sacroiliac joint } \\
\text { injection. }\end{array}$ & $\begin{array}{l}\text { Therapeutic sacroiliac } \\
\text { joint injections were } \\
\text { administered in } \\
\text { conjunction with } \\
\text { physical therapy. }\end{array}$ & $\begin{array}{l}\text { An average of } 2.1 \\
\text { therapeutic injections were } \\
\text { administered. A significant } \\
\text { reduction }(\mathrm{P}=0.0014) \text { in } \\
\text { Oswestry disability score, } \\
\text { and improvement in VAS } \\
\text { pain scores. }\end{array}$ & $\begin{array}{l}\text { Positive short-term } \\
\text { and long-term }\end{array}$ \\
\hline
\end{tabular}




\section{Radiofrequency Neurotomy}

Percutaneous radiofrequency neurotomy of sacroiliac joint innervation has been described to provide long-term relief. Our literature search yielded 52 reports. There were 7 relevant reports available for review (126-132). Of these, 4 were prospective $(127,130-$ $132)$, and 3 were retrospective $(126,128,129)$.

Methodological Quality

Two prospective evaluations $(127,130)$ were of 3 month follow-up. Consequently, they failed to meet inclusion criteria. Evaluation by Burnham and Yasui (131) had 12 month follow-up, thus, it was included in the evidence synthesis. Evaluation by Vallejo et al (132) used pulsed radiofrequency denervation for the treatment of sacroiliac joint syndrome. Thus, this study was also included in the evidence synthesis. Further, all of the 3 retrospective reports $(126,128,129)$ met inclusion criteria (Table 6).

\section{Study Characteristics}

Burnham and Yasui (131) published the results of an alternate method of radiofrequency neurotomy of the sacroiliac joint in a pilot study. They evaluated 9 subjects with sacroiliac joint pain confirmed by a local anesthetic joint block. They were treated with a series of radiofrequency strip lesions performed adjacent to the lateral dorsal foraminal aperture plus conventional monopolar lesionsing at the $\mathrm{L} 5$ dorsal ramus. The follow-up was at 1, 3, 6, 9, and 12 months after the procedure. After the procedure, significant reductions of back and leg pain frequency and severity, and analgesic intake were demonstrated. Complications were minimal. Overall, 8 of the 9 subjects were satisfied with the procedure. The median improvement in pain intensity was 4.1 NRS and reduction of disability was 17.8 (Oswestry Disability Scale). Overall satisfaction was $67 \%$ at 12 month follow-up.

Vallejo et al (132) from a total of 126 patients with presumptive sacroiliac joint dysfunction based on history and physical examination, performed arthrographically confirmed steroid/local anesthetic sacroiliac joint injections. Fifty-two patients or $41 \%$ had greater than $75 \%$ pain relief after 2 consecutive injections. Of these, 22 patients failed to respond to physical therapy, repeated sacroiliac joint injections and/or analgesics. These patients underwent pulsed radiofrequency denervation of the medial branch of L4, posterior primary rami of L5, and lateral branches S1 and S2. Outcome measures included visual analogue score and quality of life assessments. Sixteen patients $(73 \%)$ experienced good $(>50 \%)$ or excellent $(80 \%)$ pain relief following pulsed radiofrequency denervation. Duration of pain relief range was 6 to 9 weeks in 4 patients, 10 to 16 weeks in 5 patients, and 17 to 32 weeks in 7 patients. They also showed that quality of life scores improved significant in all measured categories. Six patients did not respond to pulsed radiofrequency denervation and had less than $50 \%$ reduction in VAS and were considered failures.

Ferrante et al (126), in a retrospective report, published the results of a consecutive series of 50 sacroiliac joint radiofrequency denervations performed in 33 patients with sacroiliac joint syndrome. All patients underwent diagnostic sacroiliac joint injections with local anesthetic before denervation. Outcome parameters included changes in visual analog pain scores, pain diagrams, physician examination including tenderness overlying the joint, SI joint pain provocation test, and range of motion of the lumbar spine, and opioid use pre- and post-denervation. The defined criteria for successful radiofrequency denervation was at least a $50 \%$ decrease in VAS for a period of at least 6 months. The results showed that 12 of 33 patients or $36 \%$ of the patients met the criteria for successful denervation. The average duration of pain relief was $12.0 \pm$ 1.2 months in responders versus $0.9 \pm 0.2$ months in non-responders $(P<.0001)$. They also noted that a positive response was associated with an atraumatic inciting event. They concluded that radiofrequency denervation of the sacroiliac joint can significantly reduce pain in selected patients with sacroiliac joint syndrome for a protracted time. With a 6-month response of only $36 \%$ of the patients, this study is judged as negative by the authors of this review.

Yin et al (129), in a retrospective audit of the effectiveness of sensory stimulation-guided radiofrequency neurotomy for the treatment of recalcitrant sacroiliac joint pain, reported results in 14 patients. They defined success as greater than $60 \%$ consistent subjective relief and greater than a $50 \%$ consistent decrease in pain score maintained for at least 6 months after the procedure. They reported that $64 \%$ of the patients experienced a successful outcome with $36 \%$ experiencing complete relief. The authors concluded that a sensory stimulation-guided approach toward the identification and subsequent radiofrequency thermocoagulation of symptomatic sacral lateral branch nerves appears to offer significant therapeutic advantages over existing therapies for the treatment of chronic sacroiliac joint complex pain. Even though 
Table 6. Description of studies evaluating radiofrequency neurotomy of sacroiliac joint

\begin{tabular}{|c|c|c|c|c|}
\hline Study & Participants & Intervention(s) & Outcome(s) & $\begin{array}{l}\text { Conclusion(s) } \\
\text { Short-term } \\
\text { relief }<3 \mathrm{mos} \text {. } \\
\text { Long-term } \\
\text { relief } \geq 3 \mathrm{mos} .\end{array}$ \\
\hline $\begin{array}{l}\text { Burnham and Yasui } \\
\text { (131) } \\
\text { Prospective, cohort } \\
\text { study } \\
\text { AHRQ score: } 5 / 8\end{array}$ & $\begin{array}{l}9 \text { patients with SIJ } \\
\text { pain. }\end{array}$ & $\begin{array}{l}\text { Patients were treated with } \\
\text { a series of RF strip lesions } \\
\text { performed adjacent to the } \\
\text { lateral dorsal foraminal aperture } \\
\text { plus conventional monopolar } \\
\text { lesioning at the L5 dorsal } \\
\text { ramus. }\end{array}$ & $\begin{array}{l}\text { Assessments in pain intensity and } \\
\text { frequency, analgesic intake, disability, } \\
\text { satisfaction with treatment, and } \\
\text { procedure complications evaluated } \\
\text { at } 1,3,6,9 \text {, and } 12 \text { months after the } \\
\text { procedure. Results showed significant } \\
\text { reductions of back and leg pain } \\
\text { frequency and severity, and analgesic } \\
\text { intake. Overall, } 8 \text { of } 9 \text { subjects were } \\
\text { satisfied with the procedure. }\end{array}$ & $\begin{array}{l}\text { Positive short- } \\
\text { term and long- } \\
\text { term relief }\end{array}$ \\
\hline $\begin{array}{l}\text { Vallejo et al (132) } \\
\text { Prospective case } \\
\text { series. } \\
\text { AHRQ score: } 5 / 8 \text {. }\end{array}$ & $\begin{array}{l}22 \text { patients failed } \\
\text { to respond to } \\
\text { repeated sacroiliac } \\
\text { joint injection and } \\
\text { medical therapy } \\
\text { after the diagnosis of } \\
\text { sacriliac joint pain } \\
\text { was confirmed by } 2 \\
\text { consecutive blocks, } \\
\text { physical therapy, . }\end{array}$ & $\begin{array}{l}\text { Pulsed radiofrequency } \\
\text { denervation of the medial } \\
\text { branch of L4, posterior primary } \\
\text { rami of L5, and lateral branches } \\
\text { S1 and S2 }\end{array}$ & $\begin{array}{l}\text { VAS score and quality of life } \\
\text { assessments. } 16 \text { patients or } 73 \% \\
\text { experienced good or excellent } \\
\text { pain relief and quality of life } \\
\text { improvement. Duration of pain } \\
\text { relief was } 6 \text { to } 9 \text { weeks in } 4 \text { patients, } \\
10 \text { to } 16 \text { weeks in } 5 \text { patients, and } 17 \\
\text { to } 32 \text { weeks in } 7 \text { patients. }\end{array}$ & $\begin{array}{l}\text { Positive short- } \\
\text { term and } \\
\text { negative long- } \\
\text { term relief }\end{array}$ \\
\hline $\begin{array}{l}\text { Ferrante et al (126) } \\
\text { AHRQ score: } 4 / 8\end{array}$ & $\begin{array}{l}33 \text { patients } \\
\text { with sacroiliac } \\
\text { syndrome. }\end{array}$ & $\begin{array}{l}\text { All patients underwent } \\
\text { diagnostic SI joint injections } \\
\text { with local anesthetic before } \\
\text { denervation. } \\
50 \text { sacroiliac joint } \\
\text { radiofrequency denervations } \\
\text { were performed in } 33 \text { patients. }\end{array}$ & $\begin{array}{l}\text { The criteria for successful RF } \\
\text { denervation were at least a } 50 \% \\
\text { decrease in VAS for a period of at least } \\
6 \text { months; } 36.4 \% \text { of patients ( } 12 \text { of } 33 \text { ) } \\
\text { met these criteria. The average duration } \\
\text { of pain relief was } 12.0+/-1.2 \text { months in } \\
\text { responders versus } 0.9+/-0.2 \text { months in } \\
\text { non-responders }(P<\text { or }=0.0001 \text { ). }\end{array}$ & $\begin{array}{l}\text { Negative short- } \\
\text { term and long- } \\
\text { term relief }\end{array}$ \\
\hline $\begin{array}{l}\text { Yin et al (129) } \\
\text { AHRQ score: } 4 / 8\end{array}$ & $\begin{array}{l}14 \text { patients } \\
\text { met inclusion } \\
\text { criteria for this } \\
\text { retrospective study. }\end{array}$ & $\begin{array}{l}\text { Sensory stimulation- } \\
\text { guided sacral lateral branch } \\
\text { radiofrequency neurotomy after } \\
\text { dual analgesic sacroiliac joint } \\
\text { deep interosseous ligament } \\
\text { analgesic testing. }\end{array}$ & $\begin{array}{l}64 \% \text { of patients experienced a } \\
\text { successful outcome, with } 36 \% \\
\text { experiencing complete relief. } 14 \% \\
\text { of patients did not achieve any } \\
\text { improvement. }\end{array}$ & $\begin{array}{l}\text { Positive short- } \\
\text { term and long- } \\
\text { term relief }\end{array}$ \\
\hline $\begin{array}{l}\text { Cohen and Abdi } \\
\text { (128) } \\
\text { AHRQ score: } 4 / 8\end{array}$ & $\begin{array}{l}9 \text { patients who } \\
\text { experienced }>50 \% \\
\text { pain relief underwent } \\
\text { RF lesioning of the } \\
\text { nerves. }\end{array}$ & $\begin{array}{l}\text { Nerve blocks of the L4-5 } \\
\text { primary dorsal rami and S1-3 } \\
\text { lateral branches innervating the } \\
\text { affected joint. } \\
\text { RF lesioning of the nerves. }\end{array}$ & $\begin{array}{l}8 \text { of } 9 \text { patients }(89 \%) \text { obtained } \\
>/=50 \% \text { pain relief from this } \\
\text { procedure that persisted at their } 9 \text { - } \\
\text { month follow-up. }\end{array}$ & $\begin{array}{l}\text { Positive short- } \\
\text { term and long- } \\
\text { term relief }\end{array}$ \\
\hline
\end{tabular}

this study included only 14 patients that met the inclusion criteria, the authors of the study as well as authors of this systematic review considered this study positive.

Cohen and Abdi (128) performed radiofrequency lesioning on 9 patients who experienced greater than $50 \%$ pain relief following nerve blocks of the L4-5 primary dorsal rami and S1-3 lateral branches innervating the affected joint. Eight of 9 patients (89\%) obtained
$50 \%$ or greater pain relief from this procedure that persisted at their 9-month follow-up. The authors concluded that in patients with sacroiliac joint pain who respond to L4-L5 dorsal rami and S1-3 lateral branch blocks, radiofrequency denervation of these nerves appears to be an effective treatment.

\section{Levels of Evidence}

The evidence for radiofrequency neurotomy in managing chronic sacroiliac joint pain is limited. 


\section{Safety and Complications}

No complications have been reported in any of the studies included in this review. However, potential complications, though rare, include infection, hematoma formation, burns, neural damage, gas and vascular particulate embolism, leakage of the drug from the joint, and other complications related to drug administration.

\section{Discussion}

This systematic evaluation of diagnostic and therapeutic interventions of the sacroiliac joint showed moderate evidence of accuracy of diagnostic sacroiliac joint blocks with a prevalence of $10 \%$ to $26.6 \%$ and a false positive rate of $20 \%$ to $22 \%$ (8-10). This evaluation showed ability of non-invasive measures including provocative tests and radiographic evaluation were not capable of making the precise diagnosis with evidence showing limited. This evaluation also showed limited evidence for the therapeutic effectiveness of intraarticular injections and radiofrequency neurotomy in managing sacroiliac joint pain.

The results of this systematic evaluation are similar to one previous systematic review (1) and reports assessing the value and validity of sacroiliac joint injections $(2,6,85)$. The literature on diagnostic and therapeutic interventions of the sacroiliac joint continues to be scarce. The literature on diagnostic sacroiliac joint injections and non-invasive diagnostic techniques is superior to the literature on therapeutic interventions. Due to the lack of significant literature, the level of evidence was low for therapeutic interventions. Consequently, it is imperative that previous studies are replicated and high quality evidence produced.

There is no doubt that sacroiliac joints are innervated and are capable of producing low back and referred pain in the lower extremity $(3,4,14,15-18,19$ 32). Diagnostic criteria for sacroiliac joint syndrome as defined by IASP (11) included pain in the region of the sacroiliac joint with possible radiation to the groin, medial buttocks, and posterior thigh; reproduction of pain by physical examination techniques that stress the joint; elimination of pain with intraarticular injection of local anesthetic; and a morphologically normal joint with demonstrable pathognomic radio- graphic abnormalities. Of this criterion, pain referral patterns have been well described (30-33). However, with regards to the second criterion, the reproduction of pain by physical examination techniques that stress the joint, positive correlations have been reported by some, while others have refuted these criterion (3268). Evaluation for the validity of non-diagnostic tests are provocative. Sacroiliac joint maneuvers were limited in this evaluation. The third criterion, described by IASP as elimination of pain with intraarticular injection of local anesthetic, was demonstrated in multiple evaluations $(8-10,33-36,39,50,51,82,83,93)$. The evidence for the third criterion described by IASP in this evaluation was strong. Finally, the last criterion describing a morphologically normal joint without demonstrable radiographic abnormalities or lack of correlation of radiographic abnormalities also has been illustrated (69-78).

The strength of the present systematic review is based on its compliance with strict criteria for evaluation of diagnostic tests as established by AHRQ (86), and QUADAS (87). Similar to the previous evaluation, the criteria for therapeutic management also included AHRQ criteria for observational studies. The inability of a physician to provide appropriate and accurate diagnosis for a patient with chronic spinal pain including that of sacroiliac joint pain continues to be frustrating. Even though, some of the recent literature suggests that sacroiliac joint pain can be diagnosed based on provocative maneuvers $(69-78,83)$, this systematic review once again affirms only limited evidence. Further well controlled studies are required to prove this assertion.

\section{Conclusion}

This systematic review showed moderate evidence for the accuracy of diagnostic sacroiliac joint injections in the diagnosis of sacroiliac joint pain. This systematic review also showed limited evidence for the accuracy of non-invasive diagnostic tests in arriving at the precision diagnosis of sacroiliac joint pathology. This systematic review also showed limited evidence for therapeutic intraarticular sacroiliac joint injections and radiofrequency neurotomy in managing chronic sacroiliac joint pain. 


\section{References}

1. McKenzie-Brown AM, Shah RV, Sehgal $\mathrm{N}$, Everett CR. A systematic review of sacroiliac joint interventions. Pain Physician 2005; 8:115-126.

2. Cohen SP. Sacroiliac joint pain: A comprehensive review of anatomy, diagnosis and treatment. Anesth Analg 2005; 101:1440-1453.

3. Foley BS, Buschbacher RM. Sacroiliac joint pain: anatomy, biomechanics, diagnosis, and treatment. Am J Phys Med Rehabil 2006; 85:997-1006.

4. Forst SL, Wheeler MT, Fortin JD, Vilensky JA. The sacroiliac joint: Anatomy, physiology and clinical significance. Pain Physician 2006; 9:61-68.

5. Hansen HC, Helm S. Sacroiliac joint pain and dysfunction. Pain Physician 2003; 6:179-189.

6. Boswell MV, Shah RV, Everett CR, Sehgal N, Mckenzie-Brown AM, Abdi S, Bowman RC, Deer TR, Datta S, Colson JD, Spillane WF, Smith HS, LucasLevin LF, Burton AW, Chopra P, Staats PS, Wasserman RA, Manchikanti L. Interventional techniques in the management of chronic spinal pain: Evidencebased practice guidelines. Pain Physician 2005; 8:1-47.

7. Zelle BA, Gruen GS, Brown S, George S. Sacroiliac joint dysfunction: Evaluation and management. Clin J Pain 2005; 21:446-455.

8. Maigne JY, Aivakiklis A, Pfefer F: Results of sacroiliac joint double block and value of sacroiliac pain provocation test in 54 patients with low back pain. Spine 1996; 21:1889-1892.

9. Manchikanti L, Singh V, Pampati V, Damron K, Barnhill R, Beyer C, Cash K. Evaluation of the relative contributions of various structures in chronic low back pain. Pain Physician 2001; 4:308-316.

10. Irwin RW, Watson T, Minick RP, Ambrosius WT. Age, body mass index, and gender differences in sacroiliac joint pathology. Am J Phys Med Rehabil 2007; 86:37-44.

11. Merskey H, Bogduk N. Classification of chronic pain. In Merskey H, Bogduk N (eds). Descriptions of Chronic Pain Syndromes and Definition of Pain Terms, 2nd ed. IASP Press, Seattle, 1994; 180181.

12. Mixter WJ, Barr JS. Rupture of the intervertebral disc with involvement of the spinal cord. N Engl J Med 1934; 211:210214.

13. Goldthwait JE, Osgood RB. A consideration of the pelvic articulations from an anatomical pathological and clinical standpoint. Boston Med Surg / 1905; 152:593-601.

14. Bernard TN, Cassidy JD. The sacroiliac syndrome. Pathophysiology, diagnosis and management. In: Frymoyer JW, ed. The adult spine: principles and practice. New York: Raven, 1991; 2107-2130.

15. Slipman CW, Whyte II WS, Chow DW, Chou L, Lenrow D, Ellen M. Sacroiliac joint syndrome. Pain Physician 2001; 4:143-152.

16. Pool-Goudzwaard A, Hoek van Dijke G Mulder P, Spoor C, Snijders C, Stoeckart $R$. The iliolumbar ligament: its influence of stability of the sacroiliac joint. Clin Biomech 2003; 18:99-105.

17. Chou LH, Slipman CW, Bhagia SM, Tsaur L, Bhat AL, Isaac Z, Gilchrist R, El Abc $\mathrm{OH}$, Lenrow DA. Inciting events initiating injection-proven sacroiliac joint syndrome. Pain Med 2004; 5:26-32.

18. Bogduk N. The sacroiliac joint. Clinical Anatomy of Lumbar Spine and Sacrum. 4th edition. Churchill Livingstone, New York, 2005 pp 173-181.

19. Murata Y, Takahashi K, Yamagata M, Takahashi Y, Shimada Y, Moriya H. Origin and pathway of sensory nerve fibers to the ventral and dorsal sides of the sacroiliac joint in rats. J Orthop Res 2001; 19:379-383.

20. Fortin JD, Kissling RO, O'Connor BL, Vilensky JA. Sacroiliac joint innervation and pain. Am J Orthop 1999; 28:687690.

21. Grob KR, Neuhuber WL, Kissling RO. Innervation of the sacroiliac joint of the human. Z Rheumatol 1995; 54:117-122.

22. Ikeda R. Innervation of the sacroiliac joint. Macroscopical and histological studies. Nippon Ika Daigaku Zasshi 1991; 58:587-596.

23. Vilensky JA, O'Connor BL, Fortin JD, Merkel GJ, Jimenez AM, Scofield BA, Kleiner JB. Histologic analysis of neural elements in the human sacroiliac joint. Spine 2002; 27:1202-1207.

24. Sakamoto N, Yamashita T, Takebayashi T, Sekine M, Ishii S. An electrophysiologic study of mechanoreceptors in the sacroiliac joint and adjacent tissues. Spine 2001; 26:E468-E471.

25. Solonen KA. The sacroiliac joint in the light of anatomical, roentgenological and clinical studies. Acta Orthop Scand 1957; 27:1-27.

26. Minaki Y, Yamashita T, Ishii S. An electrophysiological study on the mechanoreceptors in the lumbar spine and adjacent tissues. Neurol Orthop 1996; 20:23-35.

27. Manchikanti L, Boswell MV, Singh V, Han- sen HC. Sacroiliac joint pain: Should physicians be blocking lateral branches, medial branches, dorsal rami, or ventral rami? (Letter to the Editor) Reg Anesth Pain Med 2003; 28:490-491

28. Yamashita T, Cavanaugh JM, El-Bohy AA, Getchell TV, King Al. Mechanosensitive afferent units in the lumbar facet joint. J Bone Joint Surg Am 1990; 72:865-870.

29. Yamashita T, Minaki Y, Oota I, Yokogushi K, Ishii S. Mechanosensitive afferent units in the lumbar intervertebral disc and adjacent muscle. Spine 1993; 18:2252-2256.

30. Fortin JD, Dwyer AP, West S, Pier J. Sacroiliac joint: Pain referral maps upon applying a new injection/arthrography technique. Part I: Asymptomatic volunteers. Spine 1994; 19:1475-1482.

31. Fortin JD, Aprill CN, Ponthieux B, Pier J. Sacroiliac joints: Pain referral maps upon applying a new injection/arthrography technique. Part II: Clinical evaluation. Spine 1994; 19:1483-1489.

32. Slipman CW, Jackson HB, Lipetz JS, Chan KT, Lenrow D, Vresilovic EJ. Sacroiliac joint pain referral zones. Arch Phys Med Rehabil 2000; 81:334-338.

33. Schwarzer AC, Aprill CN, Bogduk M. The sacroiliac joint in chronic low back pain. Spine 1995; 20:31-37.

34. Laslett M, Young SB, Aprill CN, McDonald B. Diagnosing painful sacroiliac joints: A validity study of a McKenzie evaluation and sacroiliac provocation tests. Aust J Physiother 2003; 49:89-97.

35. Young S, Aprill CN, Laslett M. Correlation of clinical examination characteristics with three sources of chronic low back pain. Spine J 2003; 3:460-465.

36. Laslett M, Aprill CN, McDonald B, Young SB. Diagnosis of sacroiliac joint pain: a validity of individual provocation tests and composites of tests. Man Ther 2005; 10:207-218.

37. Laslett M. The value of the physical examination in diagnosis of painful sacroiliac joint pathologies. Spine 1998; 23:962-964.

38. Laslett $M$, Williams $M$. The reliability of selected pain provocation tests for sacroiliac joint pathology. Spine 1994; 19:1243-1249.

39. Laslett M, McDonald B, Tropp H, Aprill $\mathrm{CN}$, Oberg B. Agreement between diagnoses reached by clinical examination and available reference standards: a prospective study of 216 patients with lumbopelvic pain. BMC Musculoskelet Disord 2005; 6:28

40. Dreyfuss P, Michaelsen M, Pauza K, McLarty J, Bogduk N. The value of medical history and physical examination in 
diagnosing sacroiliac joint pain. Spine 1996; 21:2594-2602.

41. Dreyfuss P, Dryer S, Griffin J, Hoffman J, Walsh N. Positive sacroiliac screening tests in asymptomatic adults. Spine 1994; 19:1138-1143.

42. Fortin JD, Falco FJ. The Fortin finger test: an indicator of sacroiliac pain. $A m$ J Orthop 1997; 7:477-480.

43. Tullberg T, Blomberg S, Branth B, Johnsson R. Manipulation does not alter the position of the sacroiliac joint: A roentgen stereophotogrammatic analysis. Spine 1998; 23:1124-1129.

44. Slipman CW, Sterenfeld EB, Chou LH, Herzog R, Vresilovic E. The predictive value of provocative sacroiliac joint stress maneuvers in the diagnosis of sacroiliac joint syndrome. Arch Phys Med Rehab 1998; 79:288-292.

45. Broadhurst NA, Bond MJ. Pain provocation tests for the assessment of sacroiliac joint dysfunction. J Spin Disord 1998; 11:341-345.

46. Bogduk N. Pain provocation tests for the assessment of sacroiliac joint dysfunction. / Spinal Disord 1999; 12:357358.

47. Meijne W, van Neerbos K, Aufdemkampe $G$, van der Wurff P. Intraexaminer and interexaminer reliability of the Gillet test.J Man Phys Ther 1999; 22:4-9.

48. van der Wurff P, Hagmeijer RH, Meyne W. Clinical tests of the sacroiliac joint. A systemic methodological review. Part 1: reliability. Man Ther 2000; 5:30-36.

49. van der Wurff P, Meyne W, Hagmeije $\mathrm{RH}$. Clinical tests of the sacroiliac joint. Man Ther 2000; 5:89-96.

50. van der Wurff P, Buijs EJ, Groen GJ. Intensity mapping of pain referral areas in sacroiliac joint pain patients. $/ \mathrm{Ma}$ nipulative Physiol Ther 2006; 29:190195.

51. van der Wurff P, Buijs EJ, Groen GJ. A multitest regimen of pain provocation tests as an aid to reduce unnecessary minimally invasive sacroiliac joint procedures. Arch Phys Med Rehabil 2006; 87:10-14.

52. Horton SJ, Franz A. Mechanical diagnosis and therapy approach to assess ment and treatment of derangement of the sacroiliac joint. Man Ther 2006; Epub ahead of print.

53. Robinson HS, Brox JI, Robinson R, Bjelland E, Solem S, Telje T. The reliability of selected motion- and pain provocation tests for the sacroiliac joint. Man Thera 2006; Epub ahead of print.

54. Berthelot JM, Labat JJ, Le Goff B, Gouin F, Maugars Y. Provocative sacroiliac joint maneuvers and sacroiliac joint block are unreliable for diagnosing sacroiliac joint pain. Joint Bone Spine 2006; 73:17-23.

55. Levin U, Stenstro M CH. Force and time recording for validating the sacroiliac distraction test. Clin Biomech 2003; 18:821-826.

56. Leboeuf $C$. The sensitivity and specificity of seven lumbo-pelvic orthopedic tests and the arm-fossa test. J Manip Physiol Ther 1990; 13:138-143.

57. Kokmeyer DJ, van der Wurff P, Aufdem kampe G, Fickenscher TC. The reliability of multitest regimens with sacroiliac pain provocation tests. J ManipPhysiol Ther 2002; 25:42-48.

58. Tong HC, Heyman OG, Lado DA, Isser MM. Interexaminer reliability of three methods of combining test results to determine side of sacral restriction, sacral base position, and innominate bone position. I Am Osteopath Assoc 2006; 106:464-468.

59. Potter NA, Rothstein JM. Intertester reliability for selected clinical tests of the sacroiliac joint. Phys Ther 1985; 65:1671-1675.

6o. Strender LE, Sjoblom A, Sundell K, Ludwig R, Taube A. Interexaminer reliability in physical examination of patients with low back pain. Spine 1997; 22:814-820.

61. Rantanen P, Airaksinen O. Poor agreement between so-called sacroiliac joint tests in ankylosing spondylitis patients. J Manip Med 1989; 4:62-64.

62. Russel AS, Maksymowych W, LeClercq S. Clinical examination of the sacroiliac joints: a prospective study. Arthritis Rheum 1981; 24:1575-1577.

63. McCombe PF, Fairbank JC, Cockersole BC, Pynsent PB. 1989 Volvo Award in clinical sciences. Reproducibility of physical signs in low-back pain. Spine 1989; 14:908-918.

64. Carmichael JP. Inter- and intra-examiner reliability of palpation for sacroiliac joint dysfunction. J Manip Phys Ther 1987; 10:164-171.

66. Weiner DK, Sakamoto S, Perera S, Breuer P. Chronic low back pain in older adults: prevalence, reliability, and validity of physical examination find ings. J Am Geriatr Soc 2006; 54:11-20.

67. Simpson R, Gemmell H. Accuracy of spinal orthopaedic tests: a systemic review. Chiropr Osteopat 2006; 14:26.

68. Solomon J, Nadler SF, Prather H. Physical examination of the sacroiliac joint. In Malanga GA, Nadler SF (eds). Musculoskeletal Physical Examination: An Evidence-Based Approach. Elvevier Mos- by, Philadelphia, 2006 pp 227-249.

69. Ebraheim NA, Mekhail AO, Wiley WF, Jackson WT, Yeasting RA. Radiology of the sacroiliac joint. Spine 1997; 22: 869-876.

70. Resnik CS, Resnick D. Radiology of disorders of the sacroiliac joints. JAMA $1985 ; 253: 2863-2866$.

71. Slipman CW, Sterenfeld EB, Chou LH, Herzog R, Vresilovic E. The value of radionuclide imaging in the diagnosis of sacroiliac joint syndrome. Spine 1996; 21:2251-2254.

72. Maigne JY, Boulahdour H, Charellier G. Value of quantitative radionuclide bone scanning in the diagnosis of sacroiliac joint syndrome in 32 patients with low back pain. Eur Spine Jour 1998; 7:328331.

73. Goldberg RP, Genant HK, Shimshak R, Shames D. Applications and limitations of quantitative sacroiliac joint scintigraphy. Radiology 1978; 683-686.

74. Lantto T. The scintigraphy of sacroiliac joints: A comparison of 99-mTc-VPB and 99mTc-MDP. Eur J Nucl Med 1990; 16:677-681.

75. Lentle BC, Russell AS, Percy JS, Jackson $\mathrm{Fl}$. The scintigraphic investigation of sacroiliac disease. J Nucl Med 1977; 6:529-533.

76. Verlooy H, Mortelmans L, Vleugels S, De Roo M. Quantitative scintigraphy of the sacroiliac joints. Clin Imaging 1992; 16:230-233.

77. Hanly JG, Mitchell MJ, Barnes DC, MacMillan L. Early recognition of sacroiliitis by magnetic resonance imaging and single photon emission computed tomography. I Rheum 1994; 21:20882095.

78. Vogler JB 3rd, Brown WH, Helms CA, Genant HK. The normal sacroiliac joint: A CT study of asymptomatic patients. Radiology 1984; 151:433-437.

79. Elgafy H, Semaan HB, Ebraheim NA, Coombs RJ. Computed tomography findings in patients with sacroiliac pain. Clin Orthop Relat Res 2001; 382:112-118.

8o. Puhakka KB, Jurik AG, Schiottz-Christensen B, Hansen GV, Egund N, Christiansen JV, Stengaard-Pedersen K. MRI abnormalities of sacroiliac joints in early spondyloarthropathy: a 1-year follow-up study. Scand J Rheumatol 2004; 33:332-338.

81. Puhakka KB, Melson F, Jurik AG, Boel LW, Vesterby A, Egund N. MR imaging of the normal sacroiliac joint with correlation to histology. Skeletal Radiol 
2004; 33:15-28.

82. Katz V, Schofferman J, Reynolds J. The sacroiliac joint: a potential cause of pain after lumbar fusion to the sacrum. J Spinal Disord Tech 2003; 16:96-99.

83. Maigne JY, Planchon CA. Sacroiliac joint pain after fusion. A study with anesthetic blocks. Eur Spine J 2005; 14:654-658.

84. Bogduk N. Sacroiliac joint blocks. In Practice Guidelines for Spinal Diagnostic and Treatment Procedures, 1st edition. International Spine Intervention Society, 2004, pp 66-86.

85. Airaksinen O, Brox JI, Cedraschi C, Hildebrandt J, Klaber-Moffett J, Kovacs F, Mannion AF, Reis S, Staal JB, Ursin H, Zanoli G. Chapter 4: European guidelines for the management of chronic nonspecific low back pain. Eur Spine J 2006; 15:S192-S300.

86. West S, King V, Carey T, Lohr K, McKoy N, Sutton S, Lux L. Systems to rate the strength of scientific evidence. Evidence Report/Technology Assessment No. 47 University of North Carolina: Agency for Healthcare Research and Quality. AHRQ Publication No. 02-E016; April 2002.

87. Whiting P, Rutjes A, Reitsma J, Bossuyt P, Kleijnen J. The Development of QUADAS: A tools for the quality assessment of studies of diagnostic accuracy included in systematic reviews. $B M C$ Med Res Methodol 2003; 3:25.

88. van Tulder M, Assendelft W, Koes B, Bouter LM. Method guidelines for systematic reviews in the Cochrane Collaboration Back Review Group for Spinal Disorders. Spine 1997; 22:23232330.

89. Niemisto L, Kalso E, Malmivaara A, Seitsalo S, Hurri H; Cochrane Collaboration Back Review Group. Radiofrequency denervation for neck and back pain: a systematic review within the framework of the Cochrane collaboration back review group. Spine 2003 , 28:1877-1888.

90. Manchikanti L, Staats P, Singh V, Schultz D, Vilims B, Jasper J, Kloth D, Trescot A, Hansen H, Falasca T, Racz G, Deer T, Burton A, Helm S, Lou L, Bakhit C, Dunbar E, Atluri S, Calodney A, Hassenbusch S, Feler C. Evidence-based practice guidelines for interventional techniques in the management of chronic spinal pain. Pain Physician 2003; 6:380.

91. Manchikanti L, Heavner J, Racz GB, Mekhail NA, Schultz DM, Hansen HC, Singh V. Methods for evidence synthesis in interventional pain management.
Pain Physician 2003; 6:89-111.

92. Manchikanti L, Abdi S, Lucas LF. Evidence synthesis and development of guidelines in interventional pain management. Pain Physician 2005; 8:7386.

93. Pang WW, Mok MS, Lin ML, Chang DP, Hwang MH. Application of spinal pain mapping in the diagnosis of low back pain-analysis of 104 cases. Acta Anaesthesiol Sin 1998; 36:71-74.

94. Dussault RG, Kaplan PA, Anderson MW. Fluoroscopy-guided sacroiliac joint injections. Radiology 2000;214:273277.

95. Rosenberg JM, Quint TJ, de Rosayro AM. Computerized tomographic localization of clinically-guided sacroiliac joint injections. Clin J Pain 2000; 16:1821.

96. Hansen $\mathrm{H}$. Is fluoroscopy necessary for sacroiliac joint injections? Pain Physician 2003; 6:155-158.

97. Lord SM, Barnsley L, Bogduk N. The utility of comparative local anesthetic blocks versus placebo-controlled blocks for the diagnosis of cervical zygapophysial joint pain. Clin J Pain 1995; 11:208-213.

98. Barnsley L, Lord S, Bogduk N. Comparative local anaesthetic blocks in the diagnosis of cervical zygapophysial joint pain. Pain 1993; 55:99-106.

99. Bonica JJ. Local anesthesia and regional blocks. In Wall PD, Melzack R (eds). Textbook of Pain, 2nd ed. Churchill Livingstone, Edinburgh, 1989; pp 724-743.

100. Bonica JJ, Buckley FP. Regional analgesia with local anesthetics. In Bonica JJ (ed). The Management of Pain. Lea \& Febiger, Philadelphia, 1990; pp 18831966.

101. Boswell MV, Singh V, Staats PS, Hirsch J. Accuracy of precision diagnostic blocks in the diagnosis of chronic spinal pain of facet or zygapophysial joint origin: A systematic review. Pain Physician 2003; 6:449-456.

102. Sehgal N, Shah RV, McKenzie-Brown $A$, Everett CR. Diagnostic utility of facet (zygapophysial) joint injections in chronic spinal pain: A systematic review of evidence. Pain Physician 2005; 8:211-224.

103. Bogduk N. International spinal injection society guidelines for the performance of spinal injection procedures. Part 1. Zygapophysial joint blocks. Clin J Pain 1997; 13:285-302.

104. North RB, Kidd DH, Zahurak M, Piantadosi S. Specificity of diagnostic nerve blocks: a prospective, randomized study of sciatica due to lumbosacral disease. Pain 1996; 65:77-85.

105. Hildebrandt J. Relevance of nerve blocks in treating and diagnosing low back pain - is the quality decisive? Schmerz 2001; 15:474-483.

106. Nachemson A, Vingård E. Assessment of patients with neck and back pain: $A$ best-evidence synthesis. In Nachemson A, Jonsson E (eds). Neck and back pain. The Scientific Evidence of Causes, Diagnosis and Treatment. Lippincott Williams \& Wilkins, Philadelphia, 2000; pp 189-236.

107. Jaeschke R, Guyatt G, Lijmer J. Diagnostic tests. In Guyatt G, Rennie D (eds). Users' Guides to the Medical Literature- A Manual for Evidence-Based Clinical Practice. AMA Press, Chicago, 2002; pp 121-140.

108. Fortin JD, Vilensky JA, Merkel GJ. Can the sacroiliac joint cause sciatica? Pain Physician 2003; 6:269-271.

109. Block BM, Hobelmann JG, Murphy KJ, Grabow TS. An imaging review of sacroiliac joint injection under computed tomography guidance. Reg Anesth Pain Med 2005; 30:295-298.

110. Gaenslen FJ. Sacro-iliac arthrodesis. JAMA 1927; 89:2031-2035.

111. Luukkainen RK, Wennerstrand PV, Kautiainen HH, Sanila MT, Asikainen EL. Efficacy of periarticular corticosteroid treatment of the sacroiliac joint in non-spondylarthropathic patients with chronic low back pain in the region of the sacroiliac joint. Clin Exp Rheumatol 2002; 20:52-54.

112. Maugars $\mathrm{Y}$, Mathis C, Berthelot JM, Charlier C, Prost A. Assessment of the efficacy of sacroiliac corticosteroid injections spondyloarthropathies: a double blind study. $\mathrm{Br} /$ Rheumatol 1996; 35:767-770.

113. Karabacakoglu A, Karakose S, Ozerbil OM, Odev K.. Fluoroscopy-guided intraarticular corticosteroid injection into the sacroiliac joints in patients with ankylosing spondylitis. Acta Radiol 2002; 43:425-427.

114. Fischer T, Biedermann T, Hermann KG, Diekmann F, Braun J, Hamm B, Bollow M. Sacroiliitis in children with spondyloarthropathy: therapeutic effect of CTguided intraarticular corticosteroid injection. Rofo 2003; 175:814-821.

115. Hanly JG, Mitchell M, MacMillan L, Mosher D, Sutton E. Efficacy of sacroiliac corticosteroid injections in patients with inflammatory spondyloarthropathy: Results of a 5 month controlled study. J Rheum 2000; 27:719-722. 
116. Maugars Y, Mathis C, Vilon P, Prost A. Corticosteroid injection of the sacroiliac joint in patients with seronegative spondylarthropathy. Arthritis Rheum 1992; 35:564-568.

117. Bollow M, Braun J, Taupitz M, Haberle J, Reibhauer BH, Paris S, Mutze S, Seyrekbasan F, Wolf KJ, Hamm B. CTguided intraarticular corticosteroid injection into the sacroiliac joints in patients with spondyloarthropathy: indication and follow-up with contrast-enhanced MRI. J Comput Assist Tomogr 1996; 20:512-521.

118. Braun J, Bollow M, Seyrekbasan F, Haberle HJ, Eggens U, Mertz A, Distler A, Sieper J. Computed tomography guided corticosteroid injection of the sacroiliac joint in patients with spondyloarthropathy with sacroiliitis: clinical outcome and follow-up by dynamic magnetic resonance imaging. I Rheumatol 1996; 23:659-664.

119. Luukkainen $R$, Nissila $M$, Asikainen E, Sanila M, Lehtinen K, Alanaatu A, Kautianen $\mathrm{H}$. Periarticular corticosteroid treatment of the sacroiliac joint in patients with seronegative spondyloarthropathy. Clin Exp Rheumatol 1999; 17:88-90.

120. Gunaydin I, Pereira PL, Daikeler T, Mohren M, Trubenbach J, Schick F, Kanz L, Kotter I. Magnetic resonance imaging guided corticosteroid injection of the sacroiliac joints in patients with therapy resistant spondyloarthropathy: a pilot study. J Rheumatol 2000; 27:424-428.

121. Pereira PL, Gunaydin I, Duda SH, Trubenbach J, Remy CT, Kotter I, Kastler $B$, Claussen CD. Corticosteroid injections of the sacroiliac joint during magnetic resonance: preliminary results [in French]. J Radiol 2000; 81:223-226.

122. Pereira PL, Gunaydin I, Trubenbach J, Dammann F, Remy CT, Kotter I, Schick F, Koenig CW, Claussen CD. Interventional MR imaging for injection of sacroiliac joints in patients with sacroiliitis. AJR Am J Roentgenol 2000; 175:265-266.

123. Ojala R, Klemola R, Karppinen J, Sequeiros RB, Tervonen O. Sacro-iliac joint arthrography in low back pain: feasibility of MRI guidance. Eur J Radiol 2001; 40:236-239.

124. Slipman CW, Lipetz JS, Plastaras CT, Jackson HB, Vresilovic EJ, Lenrow DA, Braverman DL. Fluoroscopically guided therapeutic sacroiliac joint injections for sacroiliac joint syndrome. Am J Phys Med Rehabil 2001; 80:425-432.

125. Chakraverty R, Dias R. Audit of conservative management of chronic low back pain in a secondary care setting-part I: facet joint and sacroiliac joint interventions. Acupunct Med 2004; 22:207213.

126. Ferrante FM, King LF, Roche EA, Kim PS, Aranda M, Delaney LR, Mardini IA, Mannes AJ. Radiofrequency sacroiliac joint denervation for sacroiliac syn- drome. Reg Anesth Pain Med 2001; 26:137-142.

127. Gevargez A, Groenemeyer D, Schirp S, Braun M. CT-guided percutaneous radiofrequency denervation of the sacroiliac joint. Eur Radiol 2002; 12:13601365.

128. Cohen SP, Abdi S. Lateral branch blocks as a treatment for sacroiliac joint pain: a pilot study. Reg Anesth Pain Med 2003; 28:113-119.

129. Yin W, Willard F, Carreiro J, Dreyfuss P. Sensory stimulation-guided sacroiliac joint radiofrequency neurotomy: technique based on neuroanatomy of the dorsal sacral plexus. Spine 2003; 28:2419-2425.

130. Buijs EJ, Kamphuis ET, Groen GJ. Radiofrequency treatment of sacroiliac jointrelated pain aimed at the first three sacral dorsal rami: a minimal approach. Pain Clinic 2004; 16:139-146.

131. Burnham RS, Yasui Y. An alternate method of radiofrequency neurotomy of the sacroiliac joint: A pilot study of the effect of pain, function, and satisfaction. Reg Anesth Pain Med 2007; 32:12-19.

132. Vallejo R, Benyamin RM, Kramer J, Stanton $\mathrm{G}$, Joseph NJ. Pulsed radiofrequency denervation for the treatment of sacroiliac joint syndrome. Pain Med 2006: 7:429-434. 